\section{Upslope-verging back thrusts developed during downslope-directed slumping of Mass Transport Deposits}

G.I. Alsop ${ }^{1}$, S. Marco ${ }^{2}$ R. Weinberger ${ }^{3,4}$, T. Levi ${ }^{3}$,

1) Department of Geology and Petroleum Geology, School of Geosciences, University of Aberdeen, Aberdeen, UK. (e-mail: Ian.Alsop@abdn.ac.uk)

2) Department of Geosciences, Tel Aviv University, Israel.

3) Geological survey of Israel, Jerusalem, Israel.

4) Department of Geological and Environmental Sciences, Ben Gurion University of the Negev, Beer Sheva, Israel.

\section{Abstract}

While much research has recently been focussed on downslope-verging systems of gravitydriven fold and thrust belts within mass transport deposits (MTDs), rather less attention has been paid to back thrusts, which are defined as displaying the opposite vergence to the main transport direction in thrust systems. A fundamental question arises over whether back thrusts in downslope-verging MTDs record actual movement back upslope. In order to address this issue, we have examined exceptional outcrops of Pleistocene fold and thrust systems developed in MTDs around the Dead Sea Basin. Back thrusts can be interpreted in terms of a 'downslope-directed underthrust model', where material moves down slope and is driven into the footwall of the back thrust resulting in the 'jacking up' of the largely passive hangingwall. Our data support this underthrust model and include the observation that stratigraphic units may be markedly thickened (up to 250\%) in the footwall of back thrusts. This thickening is a consequence of pure shear lateral compaction as the 'wedge' of sediment is driven into the footwall to create an underthrust. In addition, back thrusts may be rotated as new back thrusts form in their footwalls, ultimately resulting in overturned thrusts. The observation that steeper back thrusts typically accommodate less displacement than gently-dipping back thrusts suggests that steepening occurred during back thrusting, and is therefore a consequence of 'footwall wedging'. Contrary to some recent interpretations, we demonstrate that back thrusts can develop in gravity-driven systems and cannot therefore be used to distinguish different emplacement mechanisms for MTDs.

Keywords: back thrust, MTD, slump, Dead Sea Basin

\section{Introduction}

While much research has recently been focussed on downslope-verging systems of gravitydriven fold and thrust belts within mass transport deposits (MTDs), rather less attention has been paid to back thrusts developed within such systems. Although this may be partially due to back thrusts being apparently absent from some seismic sections across MTD's from offshore Namibia (e.g. Butler and Paton, 2010; Scarselli et al., 2016) or offshore Brazil (e.g. Reis et al., 2016), they are undoubtedly imaged and well developed in others settings such as the Storegga Slide in the North Sea where oppositely verging thrusts create 'pop-up' blocks in the MTD (e.g. Bull et al., 2009, p.1146) or back thrusts in the Niger Delta (e.g. Corredor et al., 2005; Morley et al., 2011; Jolley et al., 2016). Back thrusts are also imaged on detailed seismic sections through mass movement induced fold and thrust belts in unconsolidated lacustrine sediments (e.g. Schnellmann et al., 2005). The presence of back thrusts observed in outcrop studies of thrust systems in orogenic belts (e.g. Butler, 1987) and gravity-driven slump systems (e.g. Farrell, 1984; Strachan and Alsop, 2006; Garci-Tortosa et al., 2011) is 
however long established and indisputable. Indeed, more than a quarter of all thrusts recorded by Garci-Tortosa et al. (2011) in a gravity-driven slump system from California are back thrusts.

Despite the widespread occurrence of back thrusts in slump systems and MTDs, the geometry and mechanics of these apparently anomalous structures, that verge back up the regional slope, have not been discussed in detail. Farrell (1984, p.733) working on slump sheets noted that "folds associated with upslope propagating faults will verge upslope" and that "faults which propagate in the opposite direction to the bulk transport direction are analogous to back thrusts in orogenic belts". Back thrusts have previously been defined in text books as those thrusts that "travel with the opposite sense" (i.e. towards the hinterland) (e.g. Ghosh, 1993, p.445), while more recently, Fossen (2016, p. 474) defines a back thrust as a "Thrust displacing the hangingwall toward the hinterland, i.e. opposite to the general thrusting direction". A simple question then arises of whether back thrusts in downslopeverging slump systems record actual movement back upslope? (i.e. opposite to the general thrusting direction). Interpreting the mechanism by which back thrusts have developed within MTDs is clearly critical when evaluating and distinguishing models of sediment deformation. Indeed, Myrow and Chen (2015, p. 641) note that "Thrusting of parts of brittle deformed beds took place in multiple orientations, although, in many cases, this was nearly oppositely oriented which is evidence against slope-generated gravity-driven transport and consistent with seismic deformation". A follow-up question may then be posed of the role that thrust geometries play in distinguishing different triggers and mechanisms of sediment deformation.

Slumps and MTDs are developed across a range of scales and settings and nearly all are considered to be gravity-driven. Although movement of material up the regional slope may be locally achieved by slumping off distinct palaeo-highs, tilted fault blocks and preexisting structural culminations (e.g. Alsop and Marco, 2011), this mechanism fails to account for the more general development of back thrusts in otherwise downslope-verging and gravity-driven fold and thrust systems.

In order to distinguish back thrusts from downslope-directed fore thrusts, a priori knowledge of the general direction of thrust transport is required, which in the case of gravity-driven MTDs is considered downslope. While this direction may be relatively simple to ascertain in modern or recent basins, it becomes increasingly debateable in ancient settings. We have therefore chosen to analyse a recent MTD system around the Dead Sea Basin in which there is no dispute about downslope directions and consequently what constitutes a downslope-directed fore thrust or upslope-verging back thrust (e.g. Alsop et al., 2016a) (Fig. 1). Our research focuses on some fundamental questions regarding back thrusts in gravity-driven MTDs, including:

i) Do back thrusts typically form in the central or downslope toe regions of MTDs?

ii) What controls the development of back thrusts in gravity-driven MTDs?

iii) What are the displacement patterns along back thrusts?

iv) When do back thrusts form within the thrust sequence?

v) How do back thrusts in MTDs compare to those in lithified rocks?

vi) Do back thrusts in gravity-driven MTDs record movement back upslope? 


\section{Geological Setting}

The Dead Sea Basin is a pull-apart basin developed between two left-stepping, parallel fault strands that define the sinistral Dead Sea Fault (Garfunkel, 1981; Garfunkel and BenAvraham, 1996) (Fig. 1a,). The Dead Sea Fault has been active since the Miocene (Nuriel et al., 2017) and during deposition of the Lisan Formation in the late Pleistocene (70-15 ka) (Haase-Schramm et al., 2004). The Lisan Formation comprises a sequence of alternating aragonite-rich and detrital-rich laminae on a sub-mm scale that are thought to represent annual varve-like cycles (Begin et al., 1974). Varve counting combined with isotopic dating suggests that the average sedimentation rate of the Lisan Formation is $\sim 1 \mathrm{~mm}$ per year (Prasad et al., 2009). Activity along the Dead Sea Fault system has resulted in numerous earthquakes with which to trigger co-seismic deformation (e.g. Levi et al., 2006, 2008; Weinberger et al., 2016) as well as soft-sediment deformation and slumping (e.g. El-Isa and Mustafa, 1986; Marco et al., 1996; Alsop and Marco 2012b, Alsop et al., 2016a). Individual MTDs within the Lisan Formation are typically $<1.5 \mathrm{~m}$ thick and are capped by undeformed horizontal beds, indicating that fold and thrust systems formed at the sediment surface (e.g. Alsop and Marco, 2013).

The Peratzim case study area (N $31^{\circ} 0449.6$ E $\left.35^{\circ} 2104.2\right)$ is located on the Am'iaz Plain, which is a down-faulted block positioned between the Dead Sea western border fault zone, which bounds the Cretaceous basin margin $\sim 2 \mathrm{~km}$ to the west, and the upstanding 10 $\mathrm{km}$ long ridge formed by the Sedom salt wall $3 \mathrm{~km}$ further east (e.g. Alsop et al., 2015, 2016b) (Fig. 1b, c). This area is ideal for the present case study concerning back thrusts cutting unlithified sediments of MTDs as it is well exposed and accessible along incised wadi walls. The varved lacustrine sequence permits high resolution mm-scale correlation of sequences across back thrusts. In addition, the nature of the surficial slumping, where overburden has not exceeded a few metres (e.g. Alsop et al., 2016a), removes many complications associated with changes in geometries and angles arising from subsequent compaction of sediments. The Lisan Formation is considered to have been water-saturated at the time of deformation, meaning that in general it is susceptible to loss of shear strength during seismicity (e.g. see Maltman, 1994a, b and references therein).

\subsection{Gravity-driven downslope slumping around the Dead Sea Basin.}

Deformation associated with co-seismic slip along bedding planes in the Lisan Formation has recently been documented by Weinberger et al. (2016). Horizontal shearing (marked by the offset of vertical clastic dykes) is developed $\sim 15$ m below the sediment surface and is considered to be created by simple shear deformation triggered by surface and S waves generated by earthquakes (Weinberger et al., 2016). Several bedding-parallel slip surfaces associated with the horizontal shearing during presumed Holocene earthquakes are developed, although none appear to generate folding within the Lisan Formation.

Together with the development of such horizontal slip surfaces created by co-seismic deformation during the Holocene, the older slumps and MTDs within the Lisan Formation are also considered to be triggered by seismic events (e.g. El Isa and Mustafa, 1986; Alsop and Marco, 2011). However, following the initial earthquake that triggers slope failure, these slumped horizons then undergo gravity-driven downslope movement toward the depocentre of the basin. This assertion is based on a number of lines of evidence outlined below. 
Firstly, $>90 \%$ of folds and thrusts in the study areas verge towards the NE (Alsop and Marco, 2012a). These structures are developed in six separate slumps sheets that display consistently oriented structures (Alsop et al., 2016a). Such uniformity is consistent with gravity-driven slumping, but much less likely with co-seismic deformation triggered by multiple earthquakes in different locations with potentially different focal mechanisms, directivity and magnitudes.

Secondly, MTDs collectively display a radial pattern of transport centred toward the Dead Sea Basin (Alsop and Marco, 2012a) (Fig. 1b). Slumps in the north are transported towards the SE, while those in the south (in the present study area) are directed towards the NE (Fig. 1b). In addition, slumping on the eastern side of the Dead Sea Basin is toward the west (El-Isa and Mustafa, 1986) and this completes the radial distribution of MTD transport (Alsop and Marco, 2012a). While such systematic regional patterns are entirely consistent with MTD emplacement being controlled by gravity-driven movement toward the depocentre of a basin, they would be highly unlikely if driven by co-seismic shearing and deformation.

Thirdly, analysis of drill cores from the central part of the Dead Sea Basin reveals that the Lisan Formation is three times thicker than its onshore equivalent (Marco and Kagan, 2014). This increase in thickness is attributed to the emplacement of multiple MTDs that translated downslope towards the depocentre of the basin. Such an increase in thickness supports large-scale gravity-driven transport of MTDs, resulting in the transfer of significant amounts of sediment into the deep basin.

Fourthly, fold and thrust systems define intricate relationships, with small scale systems being marked by upslope (SW) extension and attenuation, while the downslope (NE) domain is marked by contractional thrusts (e.g. Alsop and Marco, 2014;). On the scale of individual MTDs, the amount of contraction has also been shown to systematically decrease downslope towards the 'open-ended' toe (Alsop et al., 2016a). While such systematic spatial arrangement of deformational domains is consistent with gravity-driven MTDs across a range of scales and settings, they are not characteristic of co-seismic shearing where extension and contraction would be more variably orientated and distributed.

Although the very gentle or 'negligible' slopes $\left(<1^{\circ}\right)$ recorded in the Lisan Formation (Alsop and Marco, 2013) could be considered insufficient to drive slumping, they are consistent with slumping down similar low-angle slopes frequently recognised elsewhere (e.g. Lewis, 1971; Almagor and Garfunkel, 1979; Gibert et al., 2005; Garci-Tortosa et al., 2011; Gladkov et al., 2016). In some cases on modern slopes, gradients as low as $0.25^{\circ}$ are marked by gravity-driven downslope movement (e.g. Wells et al., 1980; Field et al., 1982) thereby demonstrating that such low angles are not an issue to downslope movement. Furthermore, it has also been demonstrated via analogue experiments (e.g. Owen, 1996) that such low gradients are capable of driving sediment deformation.

The observations listed above collectively confirm the gravity-driven mechanism of MTD emplacement around the Dead Sea Basin (Alsop et al., 2016a, 2017). While initial slope failure is triggered by an earthquake which perhaps just lasts in the order of seconds (e.g. see Shani-Kadmiel et al., 2014), downslope slumping subsequently takes place under the control of gravity and generates the observed fold and thrust systems that create consistent local and regional geometries. This gravity-driven deformation, which may commence during the earthquake-triggered shaking, is completed prior to deposition of an overlying 
sedimentary 'cap' that is deposited out of suspension from ensuing seiche or tsunami waves, perhaps "in a matter of just hours or days" (Alsop et al., 2016a, p. 80). The case study area therefore allows us to further test recent assertions regarding the use of thrust structures (and back thrusts in particular) to discriminate MTDs created by seismic waves (in which back thrusts are believed to develop) from gravity-driven systems in which back thrusts are not thought to be significant (e.g. see Myrow and Chen, 2015).

\section{Orientation of thrusts and back thrusts}

Fold and thrust systems developed in gravity-driven slumps and MTD's are considered to display a systematic geometric relationship to the downslope direction that presumably controlled their development (e.g. Woodcock, 1976a, b, 1979) (Fig. 2). Within most MTDs, thrusts and associated fault propagation folds are considered to generally trend parallel to the strike of the palaeoslope, and verge in the downslope direction (e.g. Ortiz-Karpf et al., 2016) (Fig. 2). However, the recognition that back thrusts may form in such gravity-driven systems means that in these cases, the structures actually verge back up the palaeoslope (Farrell, 1984) (Fig. 2). Back thrusts which root downwards onto the same floor detachment as fore thrusts are considered to be 'primary' and are equivalent to 'pop up back thrusts' of Elliot (1981) (see also Butler, 1982, p.244) (Fig. 2). They generally form coeval with fore thrusts at the leading edge of the propagating thrust system. 'Secondary' back thrusts typically develop off fore thrust ramps, and are considered to be related to accommodation in the hangingwall anticline of fore thrusts (Fig. 2). Secondary back thrusts are equivalent to the 'antithetic back thrusts' of Mandle and Crans (1981) and are discussed further by Butler (1982, p. 244). A significant difference is that 'secondary back thrusts' do not root onto the main detachment, but rather on to the downslope-verging ramp of the fore thrust (Fig. 2).

Our data regarding back thrusts in MTDs is focussed on slump 4 of the Alsop et al. (2016a) sequence from the Peratzim area (Fig. 1c). Concentrating on back thrusts from this single event has the advantage that downslope slumping directions are well constrained, while potential inconsistencies arising from variable lithologies are reduced, thereby allowing greater focus on structural controls. We have analysed thrust and fault propagation fold geometries from wadi cuttings that are parallel to the calculated transport direction within the slump sheet, thereby removing complications associated with oblique views (see Alsop et al., 2017 for details). Back thrusts display similar strikes to fore thrusts, with the sections therefore providing ideal views of both of these sets of structures (Fig. 3a-f). In the first section, the normal to mean fold hinges trends $048^{\circ}$, while normals to associated axial planes and thrusts both strike $040^{\circ}$, which suggests the transport direction is sub-parallel $\left(\sim 2^{\circ}\right.$ anticlockwise) to the $045^{\circ}$ trending wadi wall (Fig. 3a-f). In the second section, less than 100 $\mathrm{m}$ further east, the normal to mean fold hinges trends $096^{\circ}$, while normals to associated mean axial planes and thrusts strike $101^{\circ}$ and $105^{\circ}$ respectively, which suggests the transport direction is sub-parallel $\left(\sim 10^{\circ}\right.$ clockwise) to the $090^{\circ}$ trending wadi wall (Fig. $\left.3 \mathrm{~g}-\mathrm{j}\right)$. The direction of MTD transport is considered to vary between the two sites due to the flow diverging at the toe of the slump (Alsop et al., 2016a). Our observations from wadi walls, which are parallel to the local fold and thrust transport direction, therefore provide good geometric sections across back thrusts and associated structures. 


\section{Structural analysis of upslope-verging back thrusts and folds}

Back thrusts and associated fault propagation folds develop both in defined sequences where several related back thrusts are present in the same system (Fig. 4a, b, c), or as individual structures (e.g. Fig. 4e). In some instances, fore thrust 'flats' are observed to gently transect and cut through underlying stratigraphy resulting in downslope-directed footwall cutoffs (Fig. 4b, c). Sequences of back thrusts are developed upslope of these gentle ramps (Fig. $4 a, b, c$ ). Fore thrusts display average dip angles of $25^{\circ}$ (with a maximum of $50^{\circ}$ ), while the adjacent primary back thrusts that 'root' onto the same flat have average dips of $45^{\circ}$ (maximum dip of $75^{\circ}$ ) and are consistently steeper than ramps in adjacent fore thrusts (Fig. 5a). Steeper fore thrusts are associated with steeper adjacent back thrusts (Fig. 5a). In addition, steeper fore thrusts and back thrusts generally accommodate less displacement, with back thrusts showing less displacement than for equivalent angles of fore thrusts (Fig. 5b). Where sequences of fore thrusts and back thrusts form, they typically display progressive rotations and steepening indicating piggyback systems of fore thrusts (that steepen upslope) (Fig. 2, 4a, f) and back thrusts (that steepen downslope) (Fig. 2, 4a, b). In detail, primary back thrusts are planar (e.g. Fig. 4a, b, 6a, c, g), or concave-up (i.e. steepen upwards towards the fault tip) (e.g. Fig. 2, 4a, 6e), whereas fore thrusts are more generally planar (e.g. Fig. 3a, c, e, 4a), or convex-up (i.e. flatten upwards towards the fault tip) (Fig. 2, 3c, g, i, 4c, d). Back thrusts are also observed to flatten into the underlying basal detachment, so that the footwall resembles the curving shovel of a 'bulldozer' or 'snowplough' (Fig. 2, 3i, 6e).

\section{Displacement-distance graphs through back thrusts}

In displacement-distance (D-D) analysis, we measure the distance along the hangingwall of a back thrust from a fixed reference point (' $R$ ' near the fault tip) to a marker horizon, and compare this distance with the displacement of that marker by measuring the amount of offset to the same horizon in the footwall (Muraoka and Kamata, 1983; Williams and Chapman, 1983). The process is then repeated for different markers along the length of the back thrust to create a displacement-distance (D-D) graph for that fault. As displacement on faults is typically assumed to be time-dependent, then older portions of faults accumulate the greatest displacement meaning that the point of maximum displacement on a D-D plot is typically interpreted to represent the site of fault nucleation (e.g. Ellis and Dunlap, 1988; Hedlund, 1997; Ferrill et al., 2016). In general, gentle gradients on D-D plots are interpreted to represent more rapid propagation of the thrust tip relative to slip, whereas steeper gradients represent slower propagation relative to slip (e.g. Williams and Chapman, 1983; Ferrill et al., 2016).

In the case study, displacement-distance (D-D) graphs of primary back thrusts display a range of relationships including simple linear patterns, with displacement increasing progressively downwards away from the fault tip and towards the underlying basal detachment (Fig 6a, b). D-D graphs may also display non-linear patterns, with displacement gradients reducing markedly towards the underlying detachment (Fig $6 \mathrm{c}, \mathrm{d}$ ). In other cases, there are distinctive jumps in displacement where the back thrust cuts thickened units in its footwall, with footwall thickening causing pronounced displacement gradients (Fig 6 e, f, g, 
h). In some cases the sequence in the footwall of the back thrust displays extreme thickening when compared to the same units in the hangingwall, ranging between $100 \%$ (Fig. 3i), 170\% (Fig. 6c) and $250 \%$ (Fig. 6e) thickening. These values equate to the relative stretch $\left(\varepsilon_{\mathrm{r}}\right)$ which can be calculated by measuring the ratio of the measured lengths of the hangingwall $\left(l_{h}\right)$ and footwall $\left(l_{\mathrm{f}}\right)$ cut-offs parallel to the thrust, (where $\varepsilon_{\mathrm{r}}=\mathrm{l}_{\mathrm{h}}$ over $\mathrm{l}_{\mathrm{f}}$ ) (e.g. Noble and Dixon, 2011, p.72). Values of $100 \%$ thickening represent $\varepsilon_{\mathrm{r}} 0.5,170 \%$ is equivalent to $\varepsilon_{\mathrm{r}} 0.37$, while $250 \%$ thickening equates to $\varepsilon_{\mathrm{r}} 0.28$.

In all the back thrusts that were analysed, the greatest displacement is developed where the back thrust branches from the underlying basal detachment, suggesting that back thrusts propagate upwards from this lower detachment. These relationships are different to those analysed in fore thrusts, where the greatest displacement may develop where the fore thrust cuts a competent unit in the hangingwall of the detachment (Alsop et al., 2017). In addition, back thrusts frequently lack well-developed footwall synclines, especially low down next to the basal detachment, although footwall synclines become more pronounced higher up the back thrust (Fig. 6a, c, e).

\section{Back thrust sequences}

\subsection{Downslope-directed piggyback sequences}

Piggyback (or 'in sequence') thrusting develops where new thrusts form in the footwall of existing thrusts (Fig. 2). In the case study, primary back thrusts propagating from the basal detachment may cut (e.g. Fig. 4f) or simply back-steepen adjacent up slope fore thrust ramps thereby confirming the overall piggyback relationships (Fig. 4d, 3g,). Back thrusts that form near the termination of the upslope fore thrust suggest a degree of influence from the upslope thrust, and thereby also support a piggyback sequence (e.g. Fig. 4d, e). Secondary back thrusts die out upwards into tip folds that clearly fold and back steepen the next upslope thrust ramp (Fig 7a, 8a) i.e. the back thrusts post-date the upslope ramp which in a piggyback system would be the previous ramp to form. These observations are consistent with overall downslope-directed piggyback thrust sequences.

\subsection{Downslope-directed out-of-sequence thrusting}

Out-of-sequence (or 'break-back') thrusting develops where new thrusts do not get systematically younger towards the foreland (Fossen, 2016, p.485), and in fact such thrusts tend to form in the hangingwall of existing thrusts. In the case study, some back thrusts, which locally display an upslope-verging piggyback sequence, are themselves over-steepened by downslope-verging folds and fore thrusts, indicating deformation has transferred back upslope and is out-of-sequence (Fig. 7b, c, d, 8b). This may result in some back thrusts being rotated through the vertical to now display extensional geometries (Fig. 4a, 7f). In addition, individual back thrusts are also steepened by upslope fore thrusts (Fig. 4e). This backsteepening suggests continued movement of the upslope portion of the slump after the back thrusts had formed. This is consistent with out-of-sequence deformation (i.e. thrusting and shortening continue upslope).

\subsection{Upslope-directed piggyback sequences}


Where more than one back thrust is developed, then the lower (upslope) back thrust is more gently-dipping while the upper (downslope) back thrust is steeper (up to 50 ${ }^{\circ}$ ) (Fig. 4a, b, 6c, $7 \mathrm{e}, \mathrm{f}, 8 \mathrm{c})$. Over-steepened back thrusts suggest new back thrusts form in the footwall of older back thrusts thereby creating upslope-propagating piggyback sequence of back thrusts, Fig. 2). It is notable that some secondary back thrusts and folds develop in the hangingwall adjacent to where the fore thrust ramp cuts the more competent detrital marker in the footwall (Fig 3i, 4b,). These secondary back thrusts must form after the main thrust cuts the competent layer, and are therefore out-of-sequence with respect to the main fore thrusts.

\subsection{Raising of hangingwall blocks}

Back thrusts may raise their hangingwall above the general stratigraphic level within the slump sheet (e.g. Fig. 7g, h, 8d). Raising of the hangingwall is marked by a thinner detrital horizon forming the overlying sedimentary cap. This sedimentary cap was deposited from suspension following the slump event (e.g. Alsop et al., 2016a). Raising of the hangingwall of back thrusts that causes less detrital material to be deposited above it (Fig. 7g) suggests that actual uplift of the hangingwall block has occurred. It is notable that this steep secondary back thrust propagates from the point where the underlying fore thrust ramp cuts a competent unit in its footwall, suggesting that it formed in its present positon (i.e. it has not been transported by the underlying fore thrust (Fig. 7g). In addition, the observation that the basal detachment and overlying stratigraphy immediately upslope of the back thrust are lower than 'regional' and are in fact tilted downslope suggests that the whole footwall to the back thrust is being depressed and rotated during continued downslope movement from behind (Fig. $7 \mathrm{~g}$, $8 \mathrm{~d})$. It is noticeable that the footwall of some back thrusts are tilted downslope, with the underlying basal detachment then cutting through footwall stratigraphy resulting in footwall cut-offs in the downslope direction (Fig. 7c, 6e). Basal detachments cutting through tilted sequences indicates continued downslope movement on the basal detachment following creation of the back thrust.

\section{Discussion}

\subsection{Do back thrusts typically form in the central or downslope toe regions of MTDs?}

Back thrusts within gravity-driven slump systems have been shown by Garci-Tortosa et al. (2011), where the basal detachment develops along a weak (sepiolite-rich) clay horizon. Eight out of the 28 thrusts described by Garci-Tortosa et al. (2011) are back thrusts, with most of these being in the central zone of the slump, while the toe itself is dominated by downslope-verging thrusts. The development of back thrusts in the central portion of any slump could reflect weaker sediments in this area, corresponding to the point where slope failure initiates. The slump may locally decelerate downslope of the initial failure to create back thrusts, while fore thrusts are located at the toe of the slump as it potentially becomes emergent and accelerates over the sediment surface (Fig. 9a). Back thrusts would develop where there is a deceleration along the basal detachment (Fig. 9a), although fold and thrust vergence (up or down the slope) is clearly not dependent on the direction that the compressive phase migrates (see Alsop and Marco, 2011, p.435). 
In the present case study, back thrusts are developed within $\sim 100 \mathrm{~m}$ of the exposed toe of slump 4 (Alsop et al., 2016a), and may partially relate to the arrest of downslope movement within the MTD. As the toe of the slump system decelerates, the more central portion where the slump actually initiated (presumably in the weakest sediments) continues to move more rapidly downslope resulting in contraction at the toe driven from 'behind' by the upslope portion of the slump (Fig. 9b). This is supported by the observation that the frontal portions of slumps in the case study are not emergent, but rather are 'open-ended' with deformation being distributed via lateral compaction into downslope sediments (Fig. 9b) (see Alsop et al., 2016a).

\subsection{What controls the development of back thrusts in gravity-driven MTDs?}

\subsubsection{Local Thrust Pinning}

Coward (1988, p.5) suggests that back thrusts in orogenic systems could develop at tip zones where "there is a high resistance to shear and/or fault propagation". Similarly, Verges et al. (1992, p.261) suggest that a passive back thrust in the Pyrenees develops where basal friction is increased along an underlying detachment due to the removal of a lubricating salt layer. An increase in basal friction causes the overlying sequence to be driven as a footwall wedge below the passive back thrust which is consequently uplifted. Strachan and Alsop (2006, p.466) have suggested that within slump systems, back thrusts and folds may develop where the basal detachment is temporarily 'pinned' (Fig. 10a). Such back thrusts truncate downslope-verging folds in their footwall, while the hangingwall of the back thrust preserves folds with atypical vergence back up the slope (Strachan and Alsop, 2006). No local pinning is observed within the case study, although it could be argued that the overall positioning of the back thrusts within $100 \mathrm{~m}$ of the toe of the slump (see section 7.1. above) is in itself a reflection of large scale 'pinning' brought about by a reduction in downslope movement towards the 'open-ended' toe.

\subsubsection{Downslope buttress}

The role of pre-existing geometries in 'buttressing' contractional deformation, thereby leading to the development of back thrusts in the internal portions of fold and thrust belts has been modelled by McClay and Buchanan (1992). Auchter et al. (2016) have suggested that pre-existing sedimentary architecture may control the position of back thrusts in MTDs (Fig. 10b). They suggest that irregular sedimentary units may act as a 'buttress' resulting in back thrusts forming in the upslope area of the obstruction. There is no evidence of such sedimentary variation acting as a buttress in the study area. Alternatively, Fossen (2016, p.360) suggests that back thrusts form "as a result of geometric complications in ramp locations and seem to be favoured by steep ramps" (along underlying decollements) that would act as a buttress. In the study area, footwall cut-offs are indeed occasionally observed along the basal detachment immediately down slope of back thrust sequences (Fig. 4c).

\subsubsection{Angle of slope}

While significant downslope gradients may encourage forward propagation of fore thrusts in a piggyback sequence (Fig. 10c), a reduction in slope angle such that it becomes negligible $\left(<1^{\circ}\right)$ will hinder forward propagation and facilitate back thrusting (Fig. 10d). Garcia-Tortosa 
et al. (2011) record numerous back thrusts developed in slump systems formed on very gentle $\left(<1^{\circ}\right)$ slopes in lacustrine settings. Similarly, Gladkov et al. (2016) have also recorded both fore thrusts and back thrusts on gentle slopes $\left(1^{\circ}-3^{\circ}\right)$ in lacustrine settings, and suggested that these events are seismically triggered. Very gentle or negligible gradients $\left(<1^{\circ}\right)$ apply in the present system (Alsop and Marco, 2013). We suggest that the well-developed stratigraphy formed in lacustrine settings, coupled with a seismic trigger on a gentle slope, may encourage back thrusting to develop during gravity-driven downslope movement (Fig. 10d). Low or negligible gradients will hinder the forward propagation of the slump toe, thereby encouraging shortening and back thrusting driven by continued downslope movement from behind the toe (see section 7.1.) (Fig. 10d).

\subsubsection{Weak basal detachment}

Some studies suggest that back thrusts form when there is very low viscosity/friction along basal decollement. Lui et al. (1992) ran analogue experiments and noted that the number of back thrusts associated with each foreland-vergent thrust decreases with an increase in basal friction. Low values of basal friction resulted in deformation being split equally into fore thrusts and back thrusts. Mastrogiacomo et al. (2012) studied back thrusts developed in slumps in carbonates and suggest a lithological control with thinner slumps in laminated muds seemingly favouring back thrusts due to different boundary conditions along the base of the slump sheet. Weak basal detachments have been invoked in the present case study area (Alsop and Marco, 2014;) and together with very low gradients (Alsop and Marco, 2013), appear to be the most significant controls (Fig. 10d).

\subsection{What are the displacement patterns along back thrusts?}

Primary back thrusts in unlithified sediments display displacement-distance (D-D) patterns marked by the largest displacement being adjacent to the underlying detachment (Fig. 6a-h). This pattern suggests that the back thrust initiates from near this basal detachment, and propagates upwards with decreasing displacement. In general, steeper back thrusts have less displacement, despite being developed in the same stratigraphic sequence as fore thrusts in slump 4 (Fig. 5b). For instance, back thrusts shown in Figs $6 \mathrm{a}$ and $6 \mathrm{~g}$ dip at $35^{\circ}$ and $30^{\circ}$ and accommodate displacement of $390 \mathrm{~mm}$ and $1042 \mathrm{~mm}$ respectively, whereas steeper back thrusts (Figs. $6 \mathrm{~b}$ and $6 \mathrm{e}$ ) dipping at $75^{\circ}$ and $63^{\circ}$ accommodate displacement of just $124 \mathrm{~mm}$ and $313 \mathrm{~mm}$ respectively. If rotation were a later process that developed after the back thrust had formed, for instance during sequential piggyback thrusting, then its highly unlikely that such a relationship would be preserved (as larger back thrusts do not 'know' how much they will be subsequently rotated). However, if the back thrust rotated and steepened as it underwent displacement, then it is likely that displacement will diminish as the rotating back thrust becomes less favourably orientated and less effective at accommodating shortening (see Butler, 1987, p. 629). If steepening of back thrusts occurs at the same time as they are displacing markers, then this can only develop by wedging and thickening of sediment in the footwall of the back thrust (see section 7.6).

\subsection{When do back thrusts form within the thrust sequence?}


Ramsay and Huber (1987, p.522) note that back thrusts form more frequently "at a late stage of tectonic evolution of the main reversed fault structure", while Strachan (2002, p.18) suggests that thrusts are in general a late stage feature in MTDs linked to 'rapid arrest' of downslope movement at the slump toe. However, physical models run by Lui et al. (1992) show that back thrusts form sequentially immediately after each foreland vergent thrust. These experiments showed that "foreland -vergent thrusts nucleate at angles of 20-25 and are always accompanied by a back thrust (initial angles 35-40') at their tips" (Lui et al. 1992, p.75). More recently, Dotare et al. (2016, p.154) have shown from analogue models that in piggyback thrust sequences, "the location of the new frontal frost seems to be constrained by its associated back-thrust", with back thrusts forming at broadly the same time as fore thrusts. In addition, Dotare et al. (2016, p.153) note that back thrusts form at the foot of the surface slope created by the previous fore thrust.

In the case study, back thrusts also form near the tips of the upslope fore thrusts (e.g. Figs 4d, e), suggesting that local slopes created by the thrusts, together with additional loading from the upslope thrust sheet, may help drive back thrusting in piggyback sequences. Our observations that primary back thrusts may locally steepen up slope fore thrusts suggest that back thrusts form at the same time as adjacent down slope fore thrusts in an overall downslope-propagating piggyback sequence. If back thrusts are steepened by continued downslope movement (e.g. Fig. 6e) then this does not deform the overlying cap and so cannot be attributed to longer term creep as suggested in some slumps within carbonates (e.g. Ortner and Kilian, 2016) and larger MTDs (e.g. Sobiesiak et al., 2016, 2017).

\subsection{How do back thrusts in MTDs compare to those in lithified rocks?}

Boyer and Elliot (1982) note that thrust faults in lithified sequences form with dip angles of $23^{\circ}$ to $45^{\circ}$ to bedding, with angles of $25^{\circ}$ being most common. Previous work in orogenic belts has also shown that back thrusts have steeper dips and higher cut-offs relative to bedding than fore thrusts (e.g. Chapple, 1978; Davis et al., 1983; Xu et al., 2015). These angles are similar to observations of thrusts cutting unlithified sediments in the case study with primary back thrust ramps also being generally steeper than fore thrusts (e.g. Fig. 3, 4a, b, 5a) (Alsop et al., 2017).

Back thrusts in the case study display extreme values of footwall thickening that range between $100 \%$ and $250 \%$ when compared to the equivalent sequence in the hangingwall (Fig. 3i, 6c, 6e). These values are comparable to relative stretch $\left(\varepsilon_{\mathrm{r}}\right)$, which compares the relative lengths of hangingwall and footwall cut-offs (e.g. Noble and Dixon, 2011, p.72). Values of relative stretch across back thrusts in the case study of between $\varepsilon_{\mathrm{r}} 0.5$ and 0.28 are significantly less than observed from thrusts cutting lithified rocks. For instance, Williams and Chapman (1983) recorded relative stretch values of between 0.5 and 0.89 from thrusts cutting lithified rocks, while general values of between 0.5 and 1 are quoted by Chapman and Williams (1984). These extreme values of relative stretch adjacent to back thrusts in the case study are considered to reflect the ability of sediments to flow and thicken compared to lithified sequences (see Alsop et al., 2017).

Van der Plujm and Marshak (2004, p.457) suggest that (secondary) back thrusts may form in the hangingwall above a ramp in the underlying decollement. Secondary back thrusts have also been recognised in seismic across large-scale fold and thrust belts with de Vera et 
al (2010, p.230) noting that "back thrusts typically nucleate from existing kink surfaces developed at the transition from the thrust ramp to the basal detachment". These are consistent with 'secondary' back thrusts in the present study, which generally form where the underlying fore thrust undergoes a change in ramp angle. Alternatively, back thrusts may form "where the front of a thrust sheet wedges between layers of strata in the foreland as it moves up and over a footwall ramp" (Van der Plujm and Marshak (2004, p.457). In the present study there is very little evidence of ramping in the underlying detachment. Using analogue experiments, Saha et al. (2016, p.111) suggest that back vergent thrusts "must be related to lower-order thrusting at the deep level" (i.e. all back thrusts are therefore secondary). This is clearly different to observations in gravity-driven thrusts in MTDs where 'deeper level' thrusting is not present. Back thrusts and fore thrusts in orogenic and MTD systems exhibit similar angular and geometric relationships to one another, but with back thrusts in MTD's displaying significantly greater footwall thickening.

\subsection{Do back thrusts in gravity-driven slump systems record movement back upslope?} Van der Plujm and Marshak (2004, p.446) define a back thrust as "a thrust on which the transport direction is opposite to the regional transport direction". This general concept has also found its way into common usage such that the Oxford dictionary of Earth Sciences defines a back thrust as a "thrust in which displacement is in an opposite direction to that of the main thrust propagation" (Allaby, 2008, p.50). So, is it feasible for back thrusts in gravity-driven mass transport deposits to transport material back up the slope in a direction opposite to the regional downslope movement? Myrow and Chen (2015 p. 632) note that "hangingwall blocks show significant up-dip transport ... which suggests that thrusting was not a response to gravitationally induced slope failure". Clearly, the correct interpretation of back thrust mechanisms can have major implications for the interpretation and genesis of a range of MTD structures and complexes.

We now discuss evidence of whether back thrusts conform to either the 'upslopedirected overthrust model', where the hangingwall of the back thrust is actively translated back up the regional slope (Fig. 11a), or the 'downslope-directed underthrust model', where material moves down slope and is driven into the footwall of the back thrust as a wedge of sediment, while the hangingwall remains largely passive (Fig. 11b). This is equivalent to passive roof back thrusts of orogenic belts and inverted sedimentary basins (e.g. Coward, 1994, p. 299). We also follow the terminology of Ramsay and Huber (1987, p.521) who simply define an overthrust as where "an overlying thrust sheet has been displaced relative to an unmoved footwall" while an underthrust is where "the footwall has moved beneath the hangingwall". As the hangingwall of a back thrust moving upslope, or its footwall moving downslope, generate the same relative sense of shear, the issue actually becomes one of determining absolute rather than relative movements. As such, any kinematic indicators which reflect relative sense of shear are of little use, and we therefore rely on overall geometries to determine absolute motion.

\subsubsection{Thickening of sequences in the footwall of back thrusts}

Thickening of sequences in the footwall of back thrusts has been depicted and discussed on an orogenic scale by Butler (1987, p. 630), who suggests that both piggyback and out-of- 
sequence break-back sequences of back thrusts are capable of being developed. If the forward (or basin-ward) propagation of the basal detachment is restricted, then a zone of pure sheardominated deformation develops hindward (upslope) of the back thrust, resulting in layer parallel compaction and thickening of units (Butler, 1987, p. 629). Such a scenario is present in the back thrusts of Peratzim, where significant footwall thickening of some units occurs (e.g. $250 \%$ on Fig. 6e), and is commonly marked by the downward deflection of some footwall markers (e.g. Fig. 3i, 6c, e, 7f). Similar downward deflection of 'pre-kinematic' footwall markers has also been observed in sandbox models of back thrusts (e.g. fig. 8 of Alsop and Marco, 2011). As equivalent beds within the case study display different thicknesses on either side of the fault, then thickening must occur after the back thrust has initiated (i.e. a pre-existing thickened layer has not simply been later offset by the fault) (e.g. Fig. 4f, 6c). This footwall thickening supports layer parallel compaction associated with the 'downslope-directed underthrust model' (Fig. 11b).

\subsubsection{Thickening of hangingwall between linked fore thrusts and back thrusts.}

In the 'upslope-directed overthrust model', the hangingwall of back thrusts would move back up the slope in a direction opposed to the fore thrusts. Fore thrusts and back thrusts moving apart in opposing directions would result in extension of the intervening hangingwall sediments (Fig. 11a). However, where back thrusts and fore thrusts are developed adjacent to one another, there is no evidence for such extension or normal faulting in the hangingwall. Indeed, sequences between oppositely dipping thrusts are frequently thickened (e.g. Fig. $3 \mathrm{~g}$, i). This hangingwall thickening, coupled with the lack of extension therefore supports the 'downslope-directed underthrust model'.

\subsubsection{Steepening of back thrusts and 'pinched synclines'}

New thrusts developing in the footwall of existing thrusts may result in significant rotation of older thrusts, which in some analogue experiments leads to rotation through the vertical (e.g. Saha et al., 2016, p. 107) (Fig. 7f, 11a, b). Butler, (1987, p. 629) noted that within orogenic fold and thrust systems, back thrusts may become steepened due to pure shear dominated deformation, and therefore incapable of accommodating significant displacements. Back thrusts within the case study are also notably steeper than fore thrusts (e.g. Figs. 4, 5a, 7c, d, $\mathrm{g}, \mathrm{h}$ ). Marked steepening of back thrusts results in some thrusts actually being rotated through the vertical and now displaying apparent extensional geometries (Fig. 6c, 7c, 7f). We attribute the steeper back thrusts to continued down slope movement that drives a wedge of sediment into the footwall of the back thrust (Fig. 11b). New back thrusts developing in the footwall of existing back thrusts may 'steepen' the existing back thrust, before the entire system is back rotated by continued downslope movement of the footwall. This steepening and rotation of back thrusts leads to a 'pinching' of synclines between the hangingwall of the back thrusts and downslope fore thrust (Fig. 3i, 4e, 7c, g 11b). Similar patterns have recently been shown for fore thrusts in analogue modelling experiments by Saha et al. (2016, p.111). We suggest that the down slope fore thrust was already present, and acted a local 'buttress' which effectively closed the 'vice' from the opposite side (Fig. 11b). This steepening of back thrusts through the vertical, coupled with 'pinching' of synclines supports the 'downslopedirected underthrust model'. 
566

567

568

569

570

571

572

573

574

575

576

577

578

579

580

581

582

583

584

585

586

587

588

589

590

591

592

593

594

595

596

597

598

599

600

601

602

603

604

605

606

607

608

\subsubsection{Footwall synclines}

The observation that footwall synclines are generally not well developed in primary back thrusts suggests a different mechanism to fore thrusts. Footwall synclines are actually least well developed where displacements on the back thrusts are greater (i.e. toward the basal detachment) (Fig. 6a-h). We suggest that footwall synclines are therefore not the product of frictional drag, where increased rotation and folding of beds would be generated by greater displacement (see discussion in Ferrill et al., 2012). It has been suggested previously that footwall synclines form where the fault is propagating downwards (see Ferrill et al., 2016, p.9). In some cases, footwall synclines may therefore fail to develop in the lower portions of back thrusts because the fault tip was propagating upwards from the basal detachment (Fig. 11b).

\subsection{5. 'Jacking up' of back thrust hangingwall}

The observation that some hangingwalls to back thrusts are raised above the general elevation is shown by a) thinning of overlying deformed layers, b) reduction in the thickness of sedimentary caps deposited from suspension above these structural highs (Fig. $7 \mathrm{~g}, 8 \mathrm{~d}$ ). Similar thinning of 'syn-kinematic' layers above back thrusts has been observed in sandbox models of thrust systems (e.g. see fig. 8 of Alsop and Marco, 2011). In addition, the same 'syn-kinematic' layers are thickened in the footwall of the back thrusts, supporting the notion that they are actually subsiding and being driven down as a 'footwall wedge'. Raising of hangingwalls could be achieved by either a) back thrusts actively moving the hangingwall upslope (Fig. 11a), or b) continued downslope movement upslope of back thrust i.e. several thrusts were active simultaneously to 'wedge' more sediment into the footwall (Fig. 11b). The observation of structural highs above back thrusts can not therefore be used to independently separate active back thrusting of the hangingwall up the slope from the 'downslope-directed underthrust model.

\subsubsection{Summary}

We argue that back thrusts do not displace material upslope because a) the footwall sequence undergoes pure shear thickening and lateral compaction as it is 'wedged in' from upslope, b) linked fore thrust to back thrust systems do not display attenuation or extension of intervening hangingwall stratigraphy as would occur if two thrusts moved in opposite directions, c) back thrusts are over steepened (to the point of overturn) due to a sediment wedge being driven in to the footwall. This results in material being expelled from between the steepened back thrust and fore thrust as the intervening syncline is 'pinched' closed (Fig. 11b). Thus, although the hangingwall is 'jacked up' by footwall wedging resulting in it lying above the 'regional' level, this need not involve actual upslope lateral movement of the hangingwall (e.g. Fig. 7g). Finally, we note the relationships where steeper back thrusts display less displacement (section 7.3, Fig. 5b). If the hangingwall of the back thrust were actively displaced upslope during sequential piggyback overthrusting, then no such displacement-steepening relationships would develop as movement on the earlier thrust would cease before the new back thrust started to back steepen it. However, these dip- 
displacement relationships are consistent with wedging and thickening of sediment in the footwall of the active back thrust during downslope-directed underthrusting.

\section{Conclusions}

While the initial trigger for slope failure is considered to be seismicity along the Dead Sea Fault, fore thrust and back thrust development within MTDs reflects subsequent gravitydriven movement down the low-angle slope. The presence of a weak detachment horizon coupled with very low gradients $\left(<1^{\circ}\right)$ is the main control on back thrust development. Back thrusts typically form towards the toe of MTDs, where downslope translation has reduced, while movement in the upslope portion continues and/or is more rapid. Over-steepened back thrusts indicate that basin-directed movement continued upslope of the back thrusts. Back thrusts form at the same time as the overall downslope-verging thrust sequence and pre-date creation of the overlying sedimentary cap deposited from suspension. Extreme thickness variations in the footwall of back thrusts (compared to thrusts cutting lithified rocks), reflects lateral compaction during continued downslope movement.

We suggest that back thrusts in gravity-driven fold and thrust systems do not represent active displacement back up the slope, but rather the driving-in of the footwall 'wedge' in a 'downslope-directed underthrust model'. In the case of MTDs, this causes a 'jacking up' and steepening of the largely passive hangingwall to the back thrust. Back thrusts that are steeply dipping typically display less displacement, suggesting that they rotated (and therefore became ineffective) during 'footwall wedging'. Contrary to some recent assertions by Myrow and Chen (2015 p.639) that variably oriented thrust planes "are inconsistent with downslope, gravity-driven failure", we have demonstrated that back thrusts with directly opposing senses of apparent displacement to adjacent fore thrusts may develop in gravity-driven systems. The further implication of our work is that the presence of back thrusts cannot therefore be used to distinguish gravity-driven fold and thrust systems in MTDs from other seismic mechanisms.

\section{Acknowledgements}

SM acknowledges the Israel Science Foundation (ISF grant No. 1436/14) and the Ministry of National Infrastructures, Energy and Water Resources (grant \#214-17-027). RW was supported by the Israel Science Foundation (ISF grant No. 1245/11).

\section{Figures}

Fig. 1 a) Tectonic plates in the Middle East. General tectonic map showing the location of the present Dead Sea Fault (DSF). b) Map of the current Dead Sea showing the position of localities referred to in the text. The arrows within the Lisan Formation represent the direction of slumping in MTD's that forms a semi-radial pattern around the Dead Sea Basin. c) Image of the light-coloured Lisan Formation at Wadi Peratzim, with the brownish Cretaceous margin to the west and the Sedom salt wall to the east.

Fig. 2 Schematic cartoon illustrating the main structural parameters and definitions of fore thrusts (T) and back thrusts (BT) within a downslope-directed Mass Transport Deposit. 
Systems of fore thrusts and back thrusts may form downslope- and upslope-directed piggyback sequences, respectively, where $\mathrm{T} 1$ develops before $\mathrm{T} 2$ etc.

Fig. 3 Photographs (a, c, e, g, i) and associated stereonets of structural data (b, d, f, h, j) from slump 4 at Peratzim (N 31 0449.6 E $\left.35^{\circ} 2104.2\right)$. b) Stereonets of thrust planes $(\mathrm{N}=6)$, and folds $(\mathrm{N}=11$ ), showing fold hinges (mean $2 / 316$ ), axial planes (mean $127 / 21 \mathrm{SW}$ ) and thrust planes (mean strike $\left.121^{\circ}\right)$. d) Stereonets of thrust planes $(\mathrm{N}=3)$, and folds $(\mathrm{N}=8)$, showing fold hinges (mean 4/323), axial planes (mean 153/17SW) and thrust planes (mean strike $\left.144^{\circ}\right)$. f) Stereonets of thrust planes $(\mathrm{N}=5)$, and folds $(\mathrm{N}=11)$, showing fold hinges (mean 1/317), axial planes (mean 116/11SW) and thrust planes (mean strike $134^{\circ}$ ). h) Stereonets of thrust planes $(\mathrm{N}=6)$, and folds $(\mathrm{N}=8)$, showing fold hinges (mean $0 / 013)$, axial planes (mean strike $022^{\circ}$ ) and thrust planes (mean strike $\left.012^{\circ}\right)$. j) Stereonets of thrust planes $(\mathrm{N}=5)$, and folds $(\mathrm{N}=8)$, showing fold hinges (mean $1 / 180$ ), axial planes (mean strike $179^{\circ}$ ) and thrust planes (mean strike $018^{\circ}$ ). Structural data on each stereonet is represented as follows: fold hinges (solid red circles), poles to fold axial planes (open blue squares), thrust planes (red great circles), poles to thrust planes (solid red squares). Calculated slump transport directions based on fold data (blue arrows) and thrust data (red arrows) are subparallel to the trend of the outcrop section (black arrows).

Fig. 4 a) Piggyback sequence of fore thrusts and primary back thrusts with b) showing an enlargement of the SW end of the section, while c) shows the basal detachment displaying footwall cut-offs at the NE end of the section. Thrusts (T) and back thrusts (BT) are sequentially numbered from oldest (1) to youngest (3). d) and e) show back thrusts that locally steepen the upslope fore thrust, indicating that back thrusts formed later in a (downslope) piggyback sequence. f) Primary back thrust that displaces the upslope fore thrust. Layers in the footwall of the back thrust displays significant thickening.

Fig. 5 a) Graph showing data from slump $4(\mathrm{~N}=12)$ where the dip of back thrusts is compared to adjacent fore thrusts. b) Graph showing that steeper fore thrusts and back thrusts in slump 4 generally accommodate less displacement $(\mathrm{N}=35)$.

Fig. 6 Photographs (a, c, e, g) and associated displacement-distance (D-D) graphs (b, d, f, h) across primary back thrusts in slump 4 . In the photographs, displaced horizons are marked by matching coloured squares (footwall) and circles (hangingwall), with displacement dying out at the fault tip (yellow circle). The associated D-D graphs show the hangingwall cut-off markers (coloured circles) defining a displacement profile drawn downwards from the fault tip (yellow circle) at the origin. Photograph a) shows that primary back thrusts may develop secondary back thrusts in their own hangingwall, while c) and e) illustrate how back thrusts may be progressively steepened and rotated as new back thrusts form in their footwalls.

Fig. 7 a) Back thrust (BT3) causing steepening of up slope fore thrust (FT1) indicating a downslope propagating sequence. Fore thrust (FT2) ramp angles display typical reductions upwards to define convex-up geometries. b) Over-steepened back thrust develops in the hangingwall of a fore thrust. c) Over-steepened back thrust and pinched syncline indicate outof-sequence thrusting and/or continued downslope movement. d) Stereonets of thrust plane, and folds ( $\mathrm{N}=9$ ), showing fold hinges (mean 3/316), axial planes (mean 145/9SW) and thrust plane (mean strike $142^{\circ}$ ). e) Primary back thrusts undergo sequential steepening indicating a 'piggyback sequence' and continued downslope movement from behind. f) Over-steepened and inverted back thrust indicates out-of-sequence thrusting and/or continued downslope movement. g) Back thrust lifts hangingwall above 'regional' level and causes upslope syncline to pinch close. $\mathrm{h}$ ) Stereonets of thrust plane, and folds $(\mathrm{N}=10)$, showing fold hinges (mean 5/313), axial planes (mean 148/15SW) and thrust plane (mean strike $165^{\circ}$ ). Structural data on each stereonet $(\mathrm{d}, \mathrm{h})$ is represented as follows: fold hinges (solid red circles), poles to 
fold axial planes (open blue squares), thrust planes (red great circles), poles to thrust planes (solid red squares). Calculated slump transport directions based on fold data (blue arrows) and thrust data (red arrows) are subparallel to the trend of the outcrop section (black arrows).

Fig. 8 Summary cartoons illustrating sequential relationships between fore thrusts $(T)$ and back thrusts (BT). Thrusts may display a) downslope-directed piggyback sequences, b) downslope-directed out-of-sequence thrusting, c) upslope-directed piggyback sequences, d) continuing downslope movement that raises the hangingwalls of back thrusts.

Fig. 9 a) Summary cartoon illustrating how slumps initiate where sediment is weakest and undergo deceleration downslope leading to back thrusts. Frontally-emergent toes are generally marked by acceleration and fore thrusts. b) Downslope deceleration associated with 'open-ended' toes results in back thrusts in the downslope toe area.

Fig. 10 Summary cartoons illustrating mechanisms for the development of fore thrusts (T) and back thrusts (BT) in mass transport deposits. Back thrusts may be encouraged by a) downslope pinning of the detachment tip, b) sedimentary or structural buttress that inhibits downslope propagation of fore thrusts. Significant slope angles encourage fore thrusts to develop (c), whereas negligible slopes coupled with weak basal detachments encourage back thrusts (d).

Fig. 11 Summary cartoon illustrating a) upslope-directed overthrust model, and b) downslope-directed underthrust model of thrust (T) and back thrust (BT) development within mass transport deposits. Systems of back thrusts may form upslope-directed piggyback sequences respectively, where BT1 develops before BT2 etc. Rather than upslope movement of the hangingwall, back thrusts are considered to reflect 'wedging' of the footwall as it undergoes downslope-directed underthrusting.

\section{References}

Allaby, M. 2008. Oxford dictionary of Earth Sciences. Oxford University Press. Oxford, UK. 654pp.

Almagor, G., Garfunkel, Z. 1979. Submarine slumping in continental margin of Israel and northern Sinai. American Association of Petroleum Geologists Bulletin 63, 324-340.

Alsop, G.I., Marco, S 2011. Soft-sediment deformation within seismogenic slumps of the Dead Sea Basin. Journal of Structural Geology 33, 433-457.

Alsop, G.I., Marco, S. 2012a. A large-scale radial pattern of seismogenic slumping towards the Dead Sea Basin. Journal of the Geological Society 169, 99-110.

Alsop, G.I., Marco, S. 2012b. Tsunami and seiche-triggered deformation within offshore sediments. Sedimentary Geology 261, 90-107.

Alsop, G.I., Marco, S. 2013. Seismogenic slump folds formed by gravity-driven tectonics down a negligible subaqueous slope. Tectonophysics 605, 48-69.

Alsop, G.I., Marco, S. 2014. Fold and fabric relationships in temporally and spatially evolving slump systems: A multi-cell flow model. Journal of Structural Geology, 63, 27-49.

Alsop, G.I., Weinberger, R., Levi, T., Marco, S. 2015. Deformation within an exposed salt wall: Recumbent folding and extrusion of evaporites in the Dead Sea Basin. Journal of Structural Geology, $70,95-118$. 
Alsop, G.I., Marco, S., Weinberger, R., Levi, T. 2016a. Sedimentary and structural controls on seismogenic slumping within Mass Transport Deposits from the Dead Sea Basin. Sedimentary Geology 344, 71-90.

Alsop, G.I., Weinberger, R., Levi, T., Marco, S. 2016b. Cycles of passive versus active diapirism recorded along an exposed salt wall. Journal of Structural Geology 84, 47-67.

Alsop, G.I., Marco, S., Levi, T., Weinberger, R. 2017. Fold and thrust systems in Mass Transport Deposits. Journal of Structural Geology 94, 98-115.

Auchter, N.C., Romans, B.W., Hubbard, S.M. 2016. Influence of deposit architecture on intrastratal deformation, slope deposits of the Tres Pasos Formation, Chile. Sedimentary Geology 341, 13-26.

Begin, Z.B., Ehrlich, A., Nathan, Y., 1974, Lake Lisan, the Pleistocene precursor of the Dead Sea: Geological Survey of Israel Bulletin, 63, p. 30.

Boyer, S.E., Elliot, D. 1982. Thrust systems. American Association of Petroleum Geologists Bulletin 66, 1196-1230.

Bull, S., Cartwright, J., Huuse, M. 2009. A review of kinematic indicators from mass-transport complexes using 3D seismic data. Marine and Petroleum Geology 26, 1132-1151.

Butler, R.W.H. 1982. The terminology of structures in thrust belts. Journal of Structural Geology 4 , 239-245.

Butler, R.W.H., 1987. Thrust sequences. Journal of the Geological Society, London, 144, 619-634.

Butler, R.W.H., Paton, D.A. 2010. Evaluating lateral compaction in deepwater fold and thrust belts: How much are we missing from "nature's sandbox"? GSA Today 20, 4-10.

Chapman, T.J., Williams, G.D. 1984. Displacement-distance methods in the analysis of fold-thrust structures and linked-fault systems. Journal of the Geological Society 141, 121-128.

Chapple, W.M. 1978. Mechanics of thin-skinned fold-and-thrust systems. Bulletin of the Geological Society of America 89, 1189-1198.

Corredor, F., Shaw, J.H., Bilotti, F., 2005. Structural styles in the deep-water fold and thrust belts of the Niger Delta. American Association of Petroleum Geologists Bulletin 89, 753-780.

Coward, M. 1988. The Moine Thrust and the Scottish Caledonides. In: Mitra, G., Wojtal, S. (Editors) Geometries and mechanisms of thrusting with special reference to the Appalachians. Geological Society of America Special paper 222, p.1-16.

Coward, M. 1994. Inversion tectonics. In Hancock, P.L. (Editor) Continental deformation. Pergamon Press, Oxford, UK. p.289-304.

Davis, D., Suppe, J., Dahlen, F.A. 1983. Mechanics of fold-and-thrust belts and accretionary wedges. Journal of Geophysical Research 88, (B2), 1153-1172.

Dotare, T., Yamada, Y., Adam, J., Hori, T., Sakaguchi, H. 2016. Initiation of a thrust fault revealed by analog experiments. Tectonophysics $684,148-156$.

de Vera, J., Granado, P., McClay, K. 2010. Structural evolution of the Orange Basin gravity-driven system, offshore Namibia. Marine and Petroleum Geology 27, 223-237

Elliot, D. 1981. The strength of rocks in thrust sheets. Eos 62, 397.

El-Isa, Z.H., Mustafa, H. 1986. Earthquake deformations in the Lisan deposits and seismotectonic implications. Geophysical Journal of the Royal Astronomical Society 86, 413-424.

Ellis, M.A., Dunlap, W.J. 1988. Displacement variation along thrust faults: implications for the development of large faults. Journal of Structural Geology 10, 183-192. 
Farrell, S.G. 1984. A dislocation model applied to slump structures, Ainsa Basin, South Central Pyrenees, Journal of Structural Geology 6, 727-736.

Ferrill, D.A., Morris, A.P., McGinnis, R.N. 2012. Extensional fault-propagation folding in mechanically layered rocks: The case against the frictional drag mechanism. Tectonophysics 576-577, p.78-85.

Ferrill, D.A., Morris, A.P., Wigginton, S.S., Smart, K.J., McGinnis, R.N., Lehrmann, D. 2016. Deciphering thrust fault nucleation and propagation and the importance of footwall synclines. Journal of Structural Geology, 85, 1-11.

Field, M.E., Gardner, J.V., Jennings, A.E., Edwards, B.D. 1982. Earthquake-induced sediment failures on a $0.25^{\circ}$ slope, Klamath River delta, California. Geology 10, 542-546.

Fossen, H. 2016. Structural Geology. $2^{\text {nd }}$ Edition. Cambridge University Press, Cambridge, UK, p.510.

Garcia-Tortosa, F.J., Alfaro, P., Gibert, L., Scott, G. 2011. Seismically induced slump on an extremely gentle slope $\left(<1^{\circ}\right)$ of the Pleistocene Tecopa paleolake (California). Geology 39, 10551058.

Garfunkel, Z., 1981. Internal structure of the Dead Sea leaky transform (rift) in relation to plate kinematics: Tectonophysics 80, p. 81-108.

Garfunkel, Z., Ben-Avraham, Z. 1996. The structure of the Dead Sea basin. Tectonophysics 26, 155176.

Ghosh, S.K., 1993. Structural geology: fundamentals and modern developments. Pergamon press 598pp.

Gibert, L., Sanz de Galdeano, C., Alfaro, P., Scott, G., Lopez Garrido, A.C. 2005. Seismic-induced slump in Early Pleistocene deltaic deposits of the Baza Basin (SE Spain). Sedimentary Geology 179, 279-294.

Gladkov, A.S., Lobova, E.U., Deev, E.V., Korzhenkov, A.M., Mazeika, J.V., Abdieva, S.V., Rogozhin, E.A., Rodkin, M.V., Fortuna, A.B., Charimov, T.A., Yudakhin, A.S. 2016. Earthquakeinduced soft-sediment deformation structures in Late Pleistocene lacustrine deposits of Issyk-Kul lake (Kyrgystan). Sedimentary Geology 344, 112-122.

Haase-Schramm, A., Goldstein, S.L., Stein, M. 2004. U-Th dating of Lake Lisan aragonite (late Pleistocene Dead Sea) and implications for glacial East Mediterranean climate change. Geochimica et Cosmochimica Acta 68, 985-1005.

Hedlund, C.A. 1997. Fault-propagation, ductile strain, and displacement-distance relationships. Journal of Structural Geology 19, 249-256.

Jolly, B.A., Lonergan, L., Whittaker, A.C., 2016. Growth history of fault-related folds and interaction with seabed channels in the toe-thrust region of the deep-water Niger delta. Marine and Petroleum Geology 70, 58-76.

Levi, T., Weinberger, R., Aïfa, T., Eyal, Y., Marco, S., 2006. Injection mechanism of clay-rich sediments into dikes during earthquakes: Geochemistry, Geophysics, and Geosystems, v. 7, no. 12, p. Q12009

Levi, T., Weinberger, R., Eyal, Y., Lyakhovsky, V., Hefez, E. 2008. Velocities and driving pressures of clay-rich sediments injected into clastic dykes during earthquakes. Geophysical Journal International 175, 1095-1107.

Lewis, K.B. 1971. Slumping on a continental slope inclined at 1-4º Sedimentology 16, 97-110.

Lui, H., McClay, K.R., Powell, D. 1992. Physical models of thrust wedges. In: McClay, K.R. (Editor) Thrust Tectonics. Chapman and Hall, London. P. 71-81. 
Maltman, A. 1994a. Prelithification Deformation. In: Hancock, P.L. (Editor) Continental deformation. Pages 143-158. Pergamon Press.

Maltman, A. 1994b. Introduction and Overview. In: Maltman, A. (Editor) The Geological Deformation of Sediments. Chapman \& Hall, London. pp. 1-35.

Mandle, G., Crans, W. 1981. Gravitational gliding in deltas. In: McClay, K.R., Price, N.J. (Editors) Thrust and Nappe Tectonics. Special Publication of the Geological Society of London 9, 41-54.

Marco, S., Kagan, E.J. 2014. Deformed sediments in the Dead Sea drill core: a long term palaeoseismic record. EGU General Assembly Conference Abstracts, vol. 16, 4375. Vienna.

Marco, S., Stein, M., Agnon, A., and Ron, H., 1996. Long term earthquake clustering: a 50,000 year paleoseismic record in the Dead Sea Graben: J. Geophys. Res., 101, 6179-6192.

Mastrogiacomo, G., Moretti, M., Owen, G., Spalluto, L. 2012. Tectonic triggering of slump sheets in the Upper Cretaceous carbonate succession of the Porto Selvaggio area (Salento peninsula, southern Italy): Synsedimentary tectonics in the Apulian Carbonate Platform. Sedimentary Geology 269-270, $15-27$.

McClay, K.R., Buchanan, P.G. 1992. Thrust faults in inverted extensional basins. In: McClay, K.R. (Editor) Thrust Tectonics. Chapman and Hall, London. P. 93-104.

Morley, C.K., King, R., Hillis, R., Tingay, M., Backe, G. 2011. Deepwater fold and thrust belt classification, tectonics, structure and hydrocarbon prospectivity: A review. Earth Science Reviews, 104, 41-91.

Muraoka, H., Kamata, H., 1983. Displacement distribution along minor fault traces. Journal of Structural Geology 5, 483-495.

Myrow, P.M., Chen, J. 2015 Estimates of large magnitude Late Cambrian earthquakes from seismogenic soft-sediment deformation structures: Central Rocky Mountains. Sedimentology 62, 621644. Doi: $10.1111 /$ sed.12154

Noble, T.E., Dixon, J.M., 2011. Structural evolution of fold-thrust structures in analog models deformed in a large geotechnical centrifuge. Journal of Structural Geology 33, 62-77.

Nuriel,P., Weinberger, R., Kylander-Clark, A.R.C., Hacker, B.R., Cradock, J.P. 2017. The onset of the Dead Sea transform based on calcite age-strain analyses. Geology doi:10.1130/G38903.1

Owen, G. 1996. Experimental soft-sediment deformation: structures formed by the liquefaction of unconsolidated sands and some ancient examples. Sedimentology 43, 279-293.

Ortiz-Karpf, A., Hodgson, D.M., Jackson, C, A-L., McCaffrey, W.D. 2016. Mass-transport complexes as markers of deep-water fold-and-thrust belt evolution: insights from the southern Magdalena fan, offshore Colombia. Basin Research doi: 10.1111/bre.12208

Ortner, H., Kilian, S. 2016. Sediment creep on slopes in pelagic limestones: Upper Jurassic of Northern Calcareous Alps, Austria. Sedimentary Geology, 344, 350-363.

Prasad, S., Negendank, J.F.W., Stein, M. 2009. Varve counting reveals high resolution radiocarbon reservoir age variations in palaeolake Lisan. Journal of Quaternary Science 24, 690-696.

Ramsay, J.G., Huber, M.I. 1987. The techniques of modern structural geology. Vol. 2, Folds and fractures. Academic Press Inc. London. 309-695p.

Reis, A.T., Araújo, E., Silva, C.G., Cruz, A.M., Gorini, C., Droz, L., Migeon, S., Perovano, R., King, I., Bache, F. 2016. Effects of a regional décollement level for gravity tectonics on late Neogene to recent large-scale slope instabilities in the Foz do Amazonas Basin, Brazil. Marine and Petroleum Geology 75, 29-52. 
Saha, P., Bose, S., Mandal, N. 2016. Sandbox modelling of sequential thrusting in a mechanically two-layered system and its implications in fold-and-thrust belts. Journal of Geodynamics 100, 104114.

Scarselli, N., McClay, K., Elders, C. 2016. Seismic geomorphology of Cretaceous megaslides offshore Namibia (Orange Basin): Insights into segmentation and degradation of gravity-driven linked systems. Marine and Petroleum Geology 75, 151-180.

Schnellmann, M., Anselmetti, F.S., Giardini, D. McKenzie, J.A. 2005. Mass-movement-induced foldand-thrust belt structures in unconsolidated sediments in Lake Lucerne (Switzerland). Sedimentology 52, 271-289.

Shani-Kadmiel, S., Tsesarsky, M., Louie, J.N., Gvirtzman, Z. 2014. Geometrical focusing as a mechanism for significant amplification of ground motion in sedimentary basins: analytical and numerical study. Bulletin of Earthquake Engineering 12, 607-625.

Sobiesiak, M., Kneller, B.C., Alsop, G.I., Milana, J.P. 2016. Internal deformation and kinematic indicators within a tripartite Mass Transport Deposit, NW Argentina. Sedimentary Geology 344, 364 381.

Sobiesiak, M., Alsop, G.I., Kneller, B.C., Milana, J.P. 2017. Sub-seismic scale folding and thrusting within an exposed mass transport deposit: A case study from NW Argentina. Journal of Structural Geology 96, 176-191.

Strachan, L.J. 2002. Slump-initiated and controlled syndepositional sandstone remobilization; an example from the Namurian of County Clare, Ireland. Sedimentology, 49, 25-41.

Strachan, L.J., Alsop, G.I. 2006. Slump folds as estimators of palaeoslope: a case study from the Fisherstreet Slump of County Clare, Ireland. Basin Research 18, 451-470.

Van der Pluijm, B.A., Marshak, S. 2004. Earth Structure: An introduction to Structural Geology and Tectonics, second ed.W.W. Norton \& Company Ltd., New York, London 656 pp.

Verges, J., Munoz, J.A., Martinez, A. 1992. South Pyrenean fold and thrust belt: The role of foreland evaporitic levels in thrust geometry. In: McClay, K.R. (Editor) Thrust Tectonics. Chapman and Hall, London. P. 255-264.

Weinberger, R., Levi, T., Alsop. G.I., Eyal, Y. 2016. Coseismic horizontal slip revealed by sheared clastic dikes in the Dead Sea basin. Geological Society of America Bulletin 128, 1193-1206.

Wells, J.T., Prior, D.B., Coleman, J.M. 1980. Flowslides in muds on extremely low angle tidal flats, northeastern South America. Geology 8, 272-275.

Williams, G., Chapman, T. 1983. Strains developed in the hangingwall of thrusts due to their slip/propagation rate: a dislocation model. Journal of Structural Geology 5, 563-571.

Woodcock, N. H 1976a. Ludlow Series slumps and turbidites and the form of the Montgomery Trough, Powys, Wales. Proceedings of the Geologists Association 87, 169-182.

Woodcock, N. H 1976b. Structural style in slump sheets: Ludlow Series, Powys, Wales. Journal of the Geological Society, London 132, 399-415.

Woodcock, N.H. 1979. The use of slump structures as palaeoslope orientation estimators. Sedimentology, 26, 83-99.

Xu, S., Fukuyama, E., Ben-Zion, Y., Ampuero, J-P. 2015. Dynamic rupture activation of backthrust fault branching. Tectonophysics 644-645, 161-183. 
Figure 1
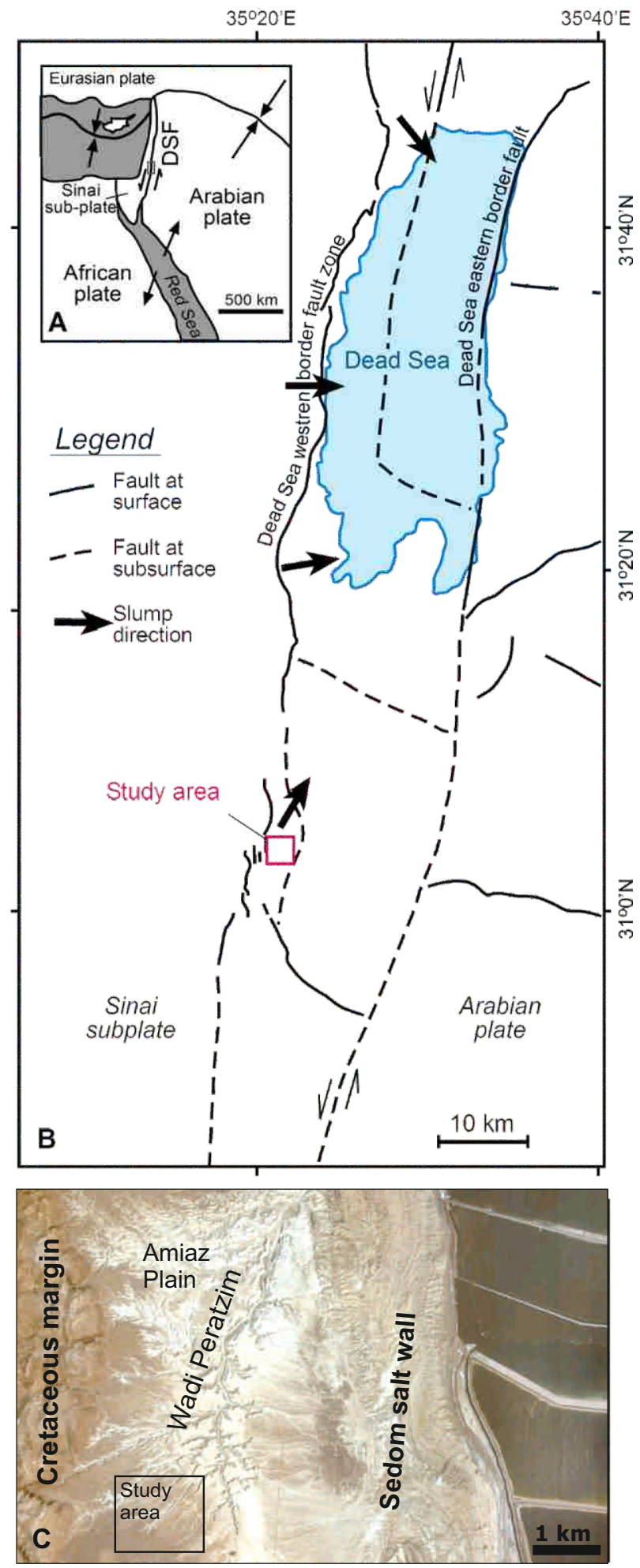


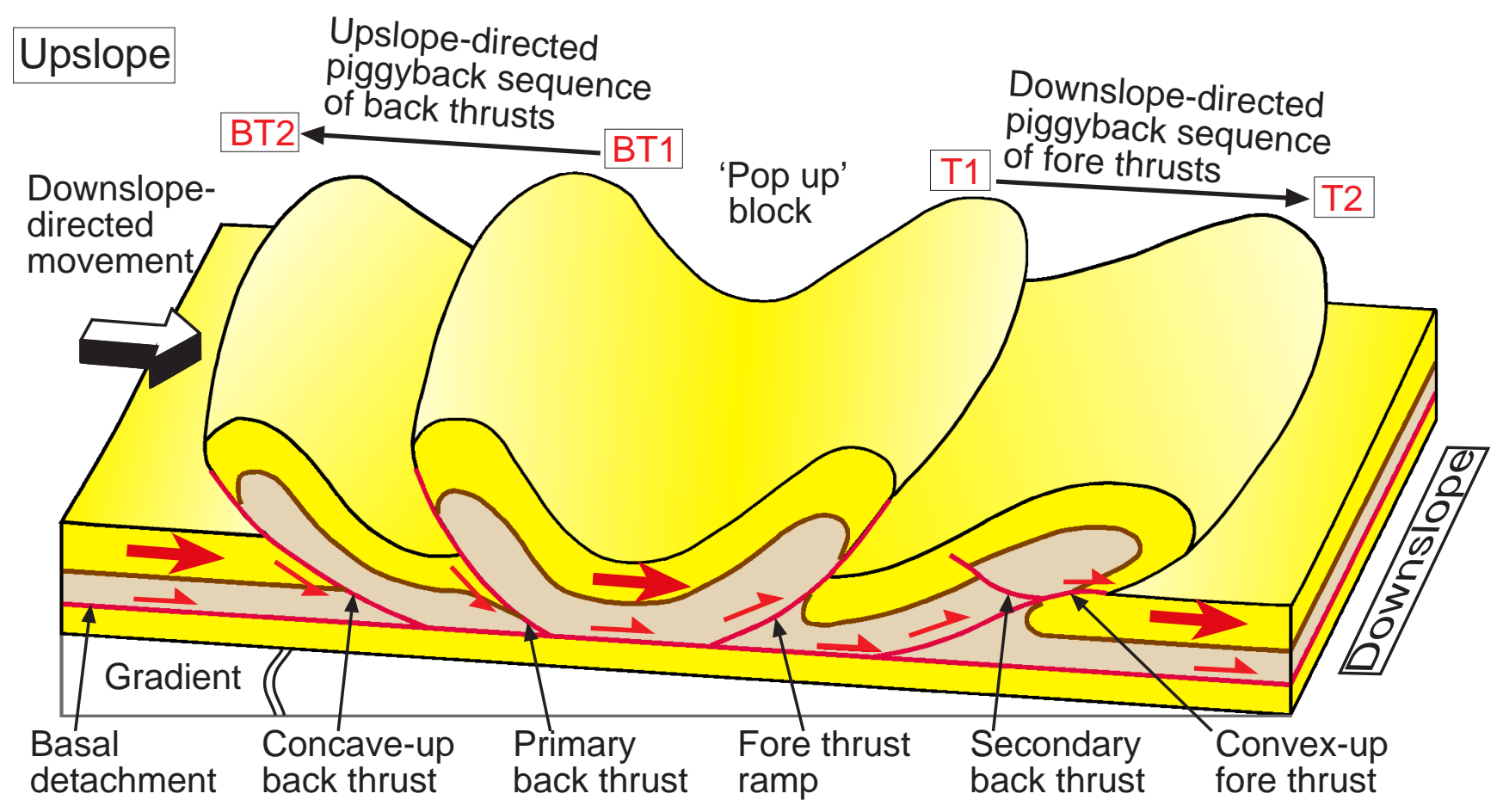



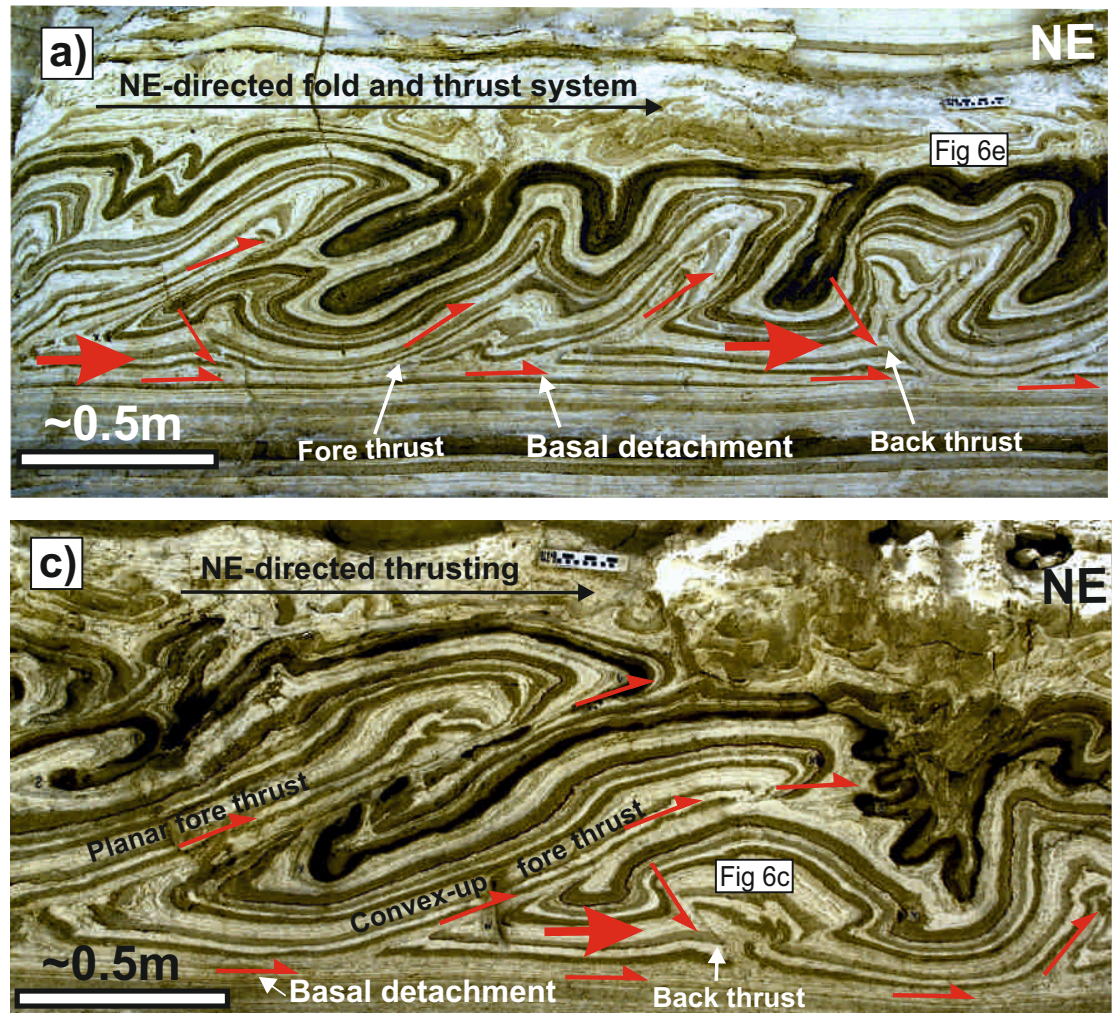

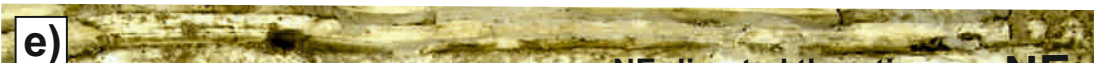
Pinched Secondary $^{2}$ NE-directed thrusting $\rightarrow$ NE syncline $\&$ back thrust Fore thrust \& Fore thrust
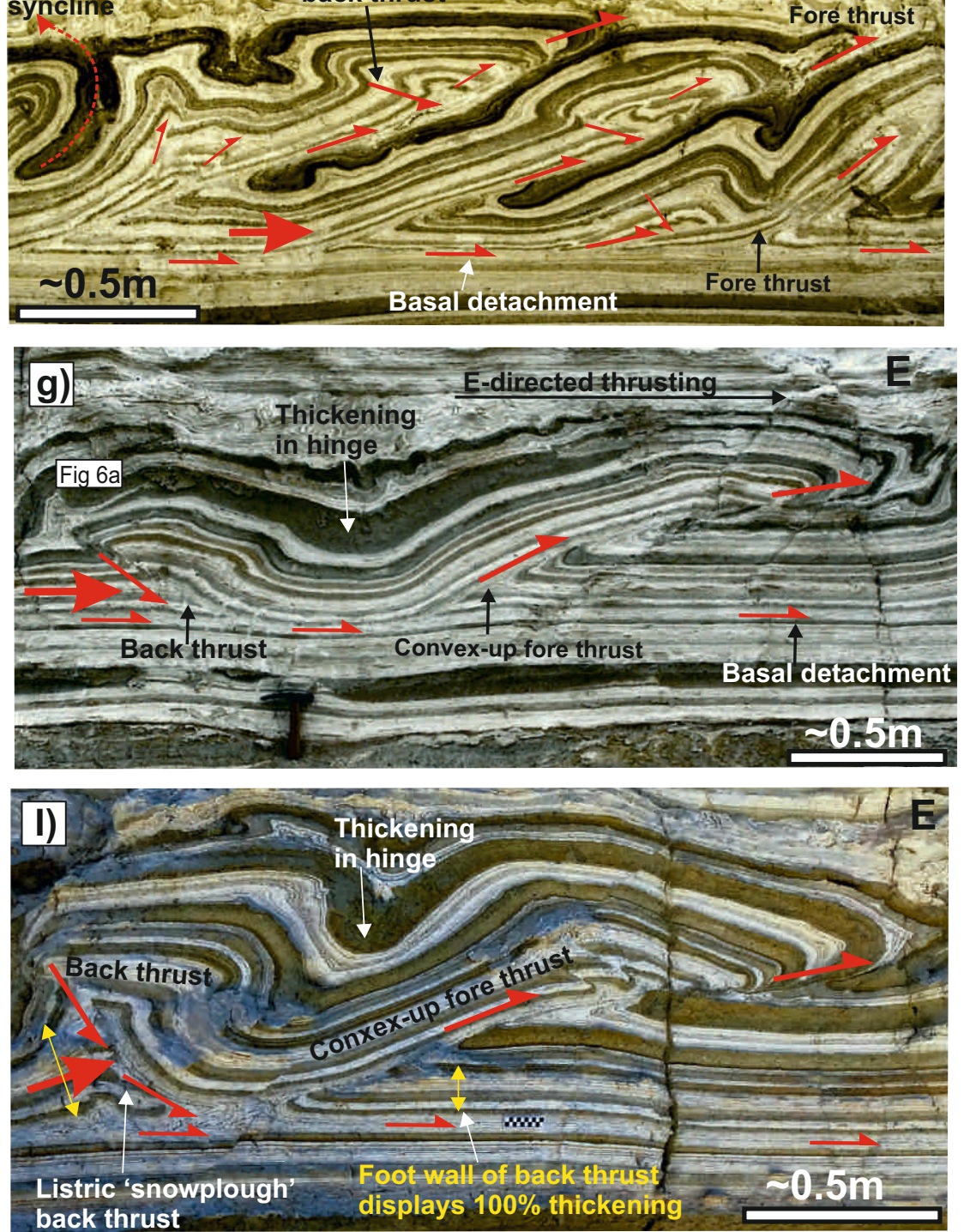
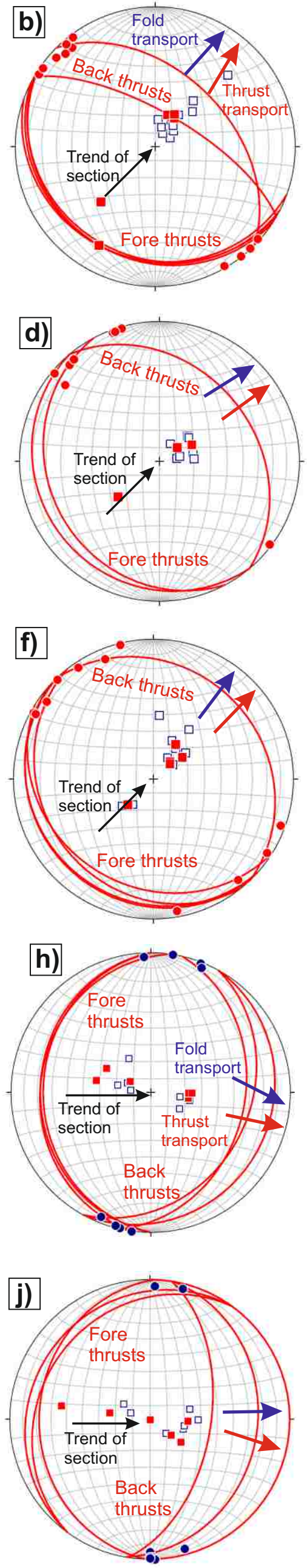

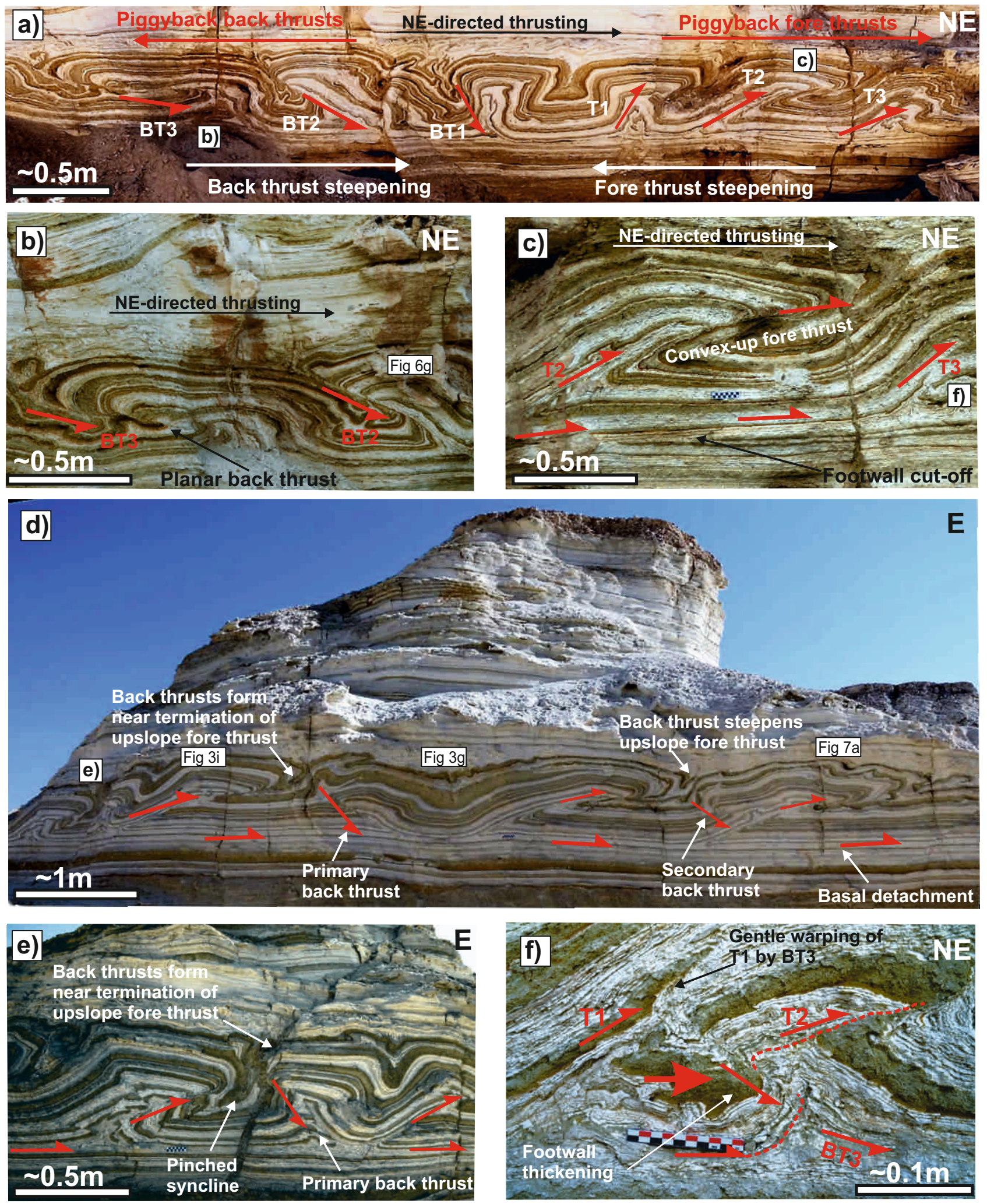
Figure 5
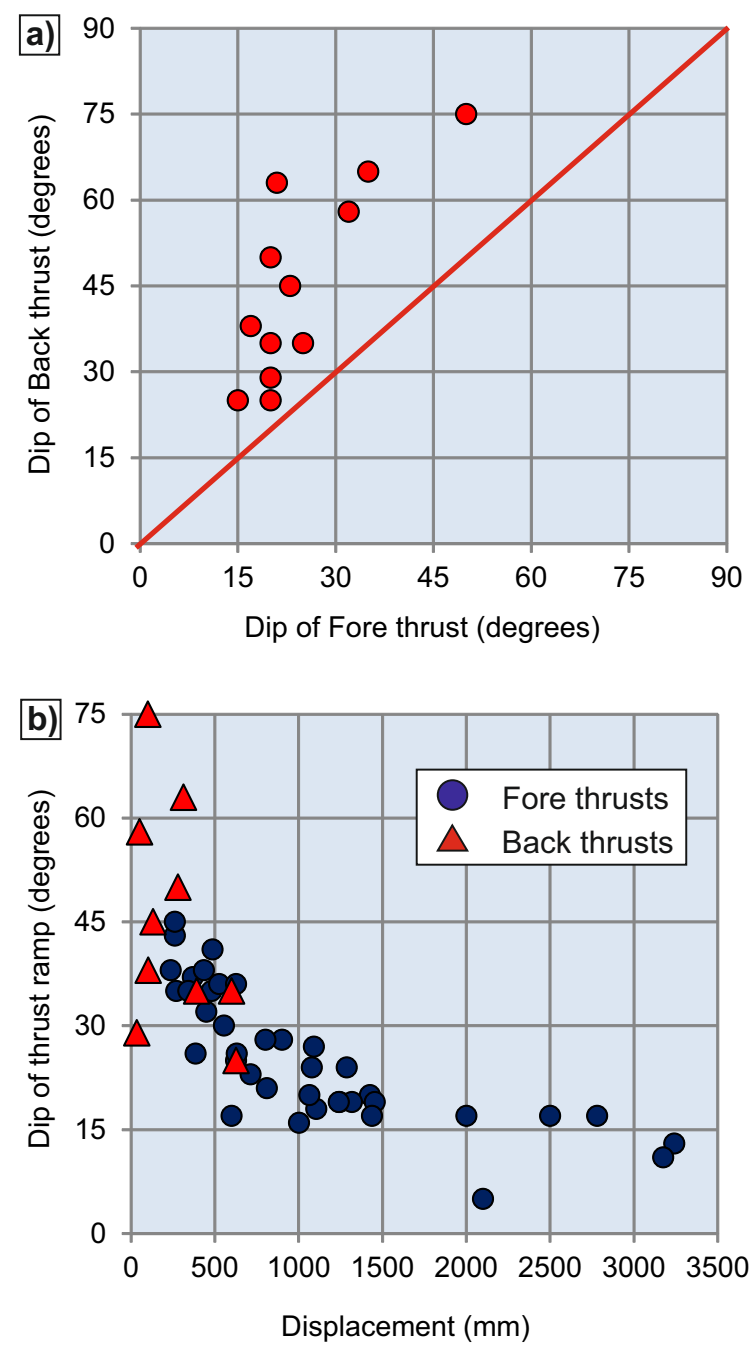

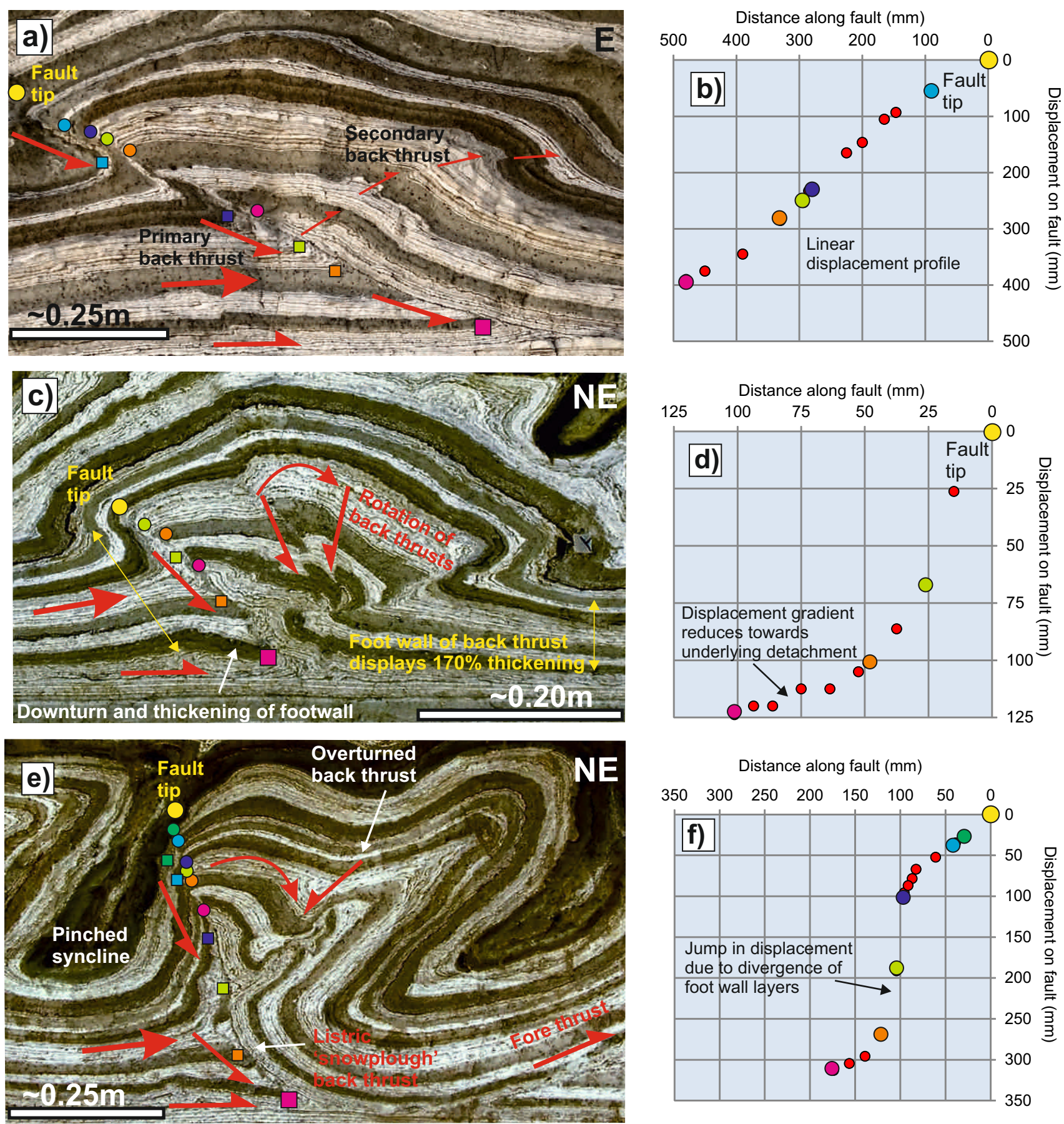

\section{Distance along fault (mm)}
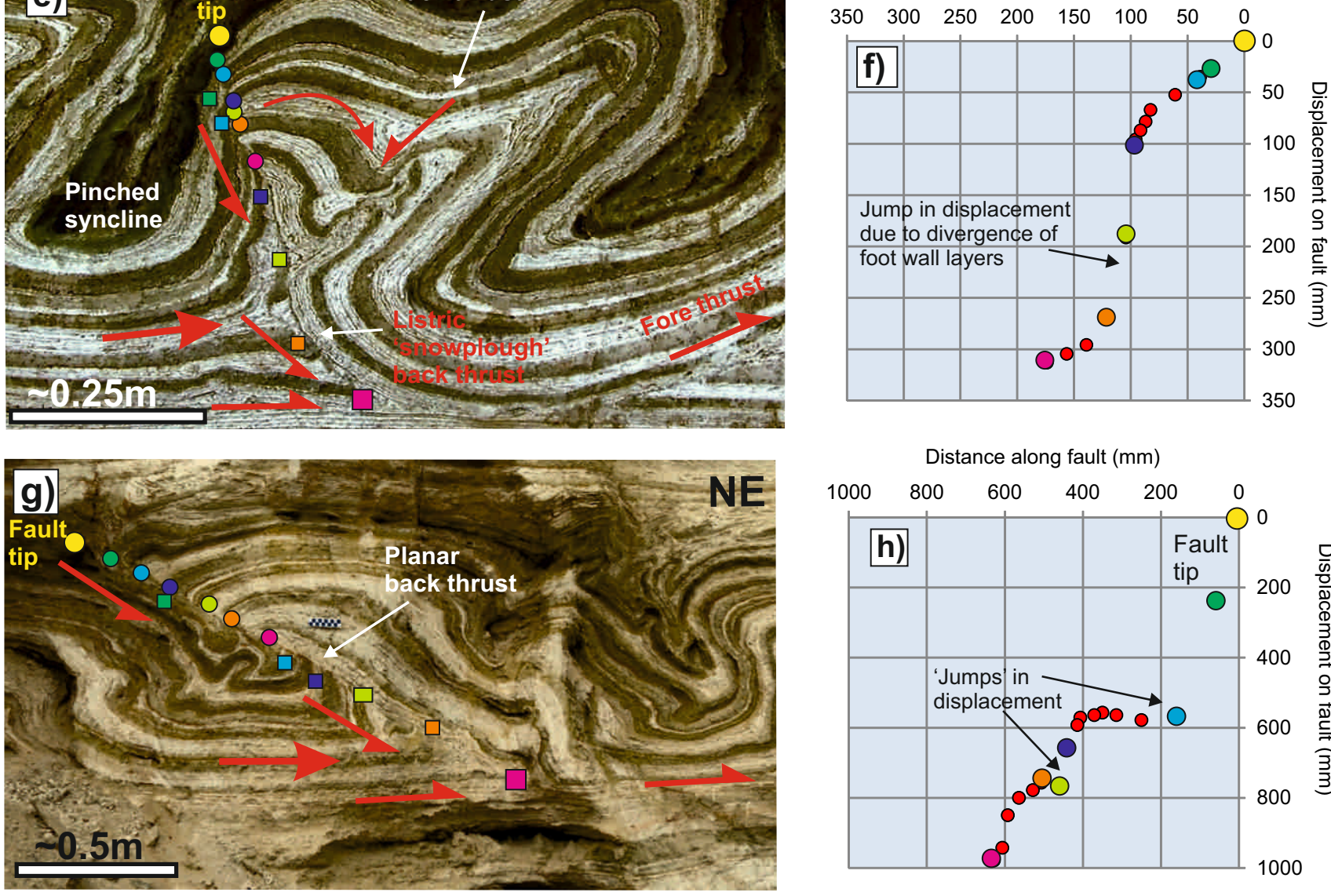

Distance along fault (mm)

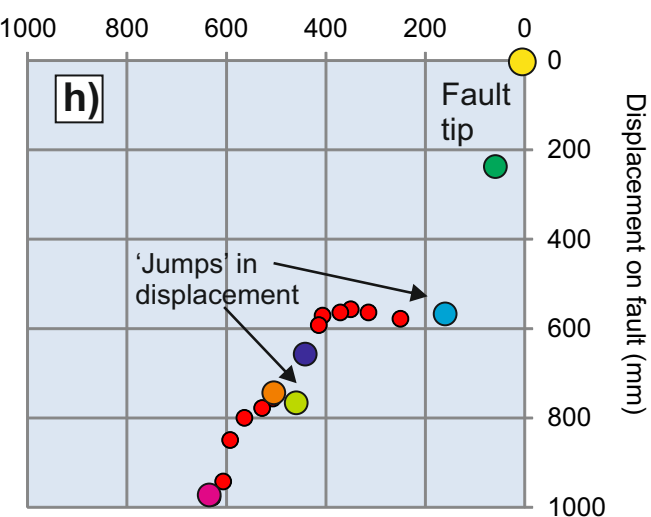



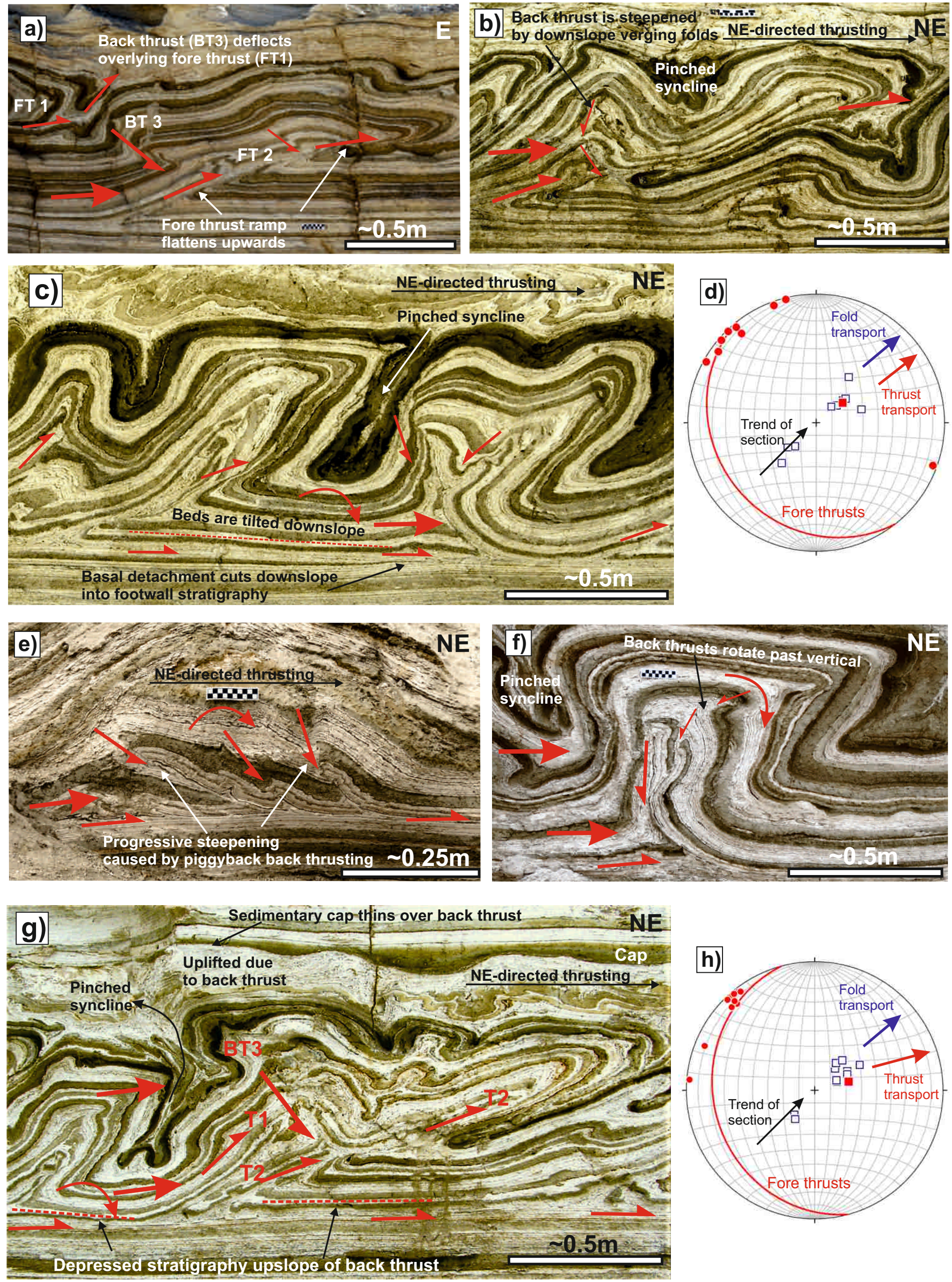
a)

Fore thrusts are back steepened

Upslope by downslope back thrusts

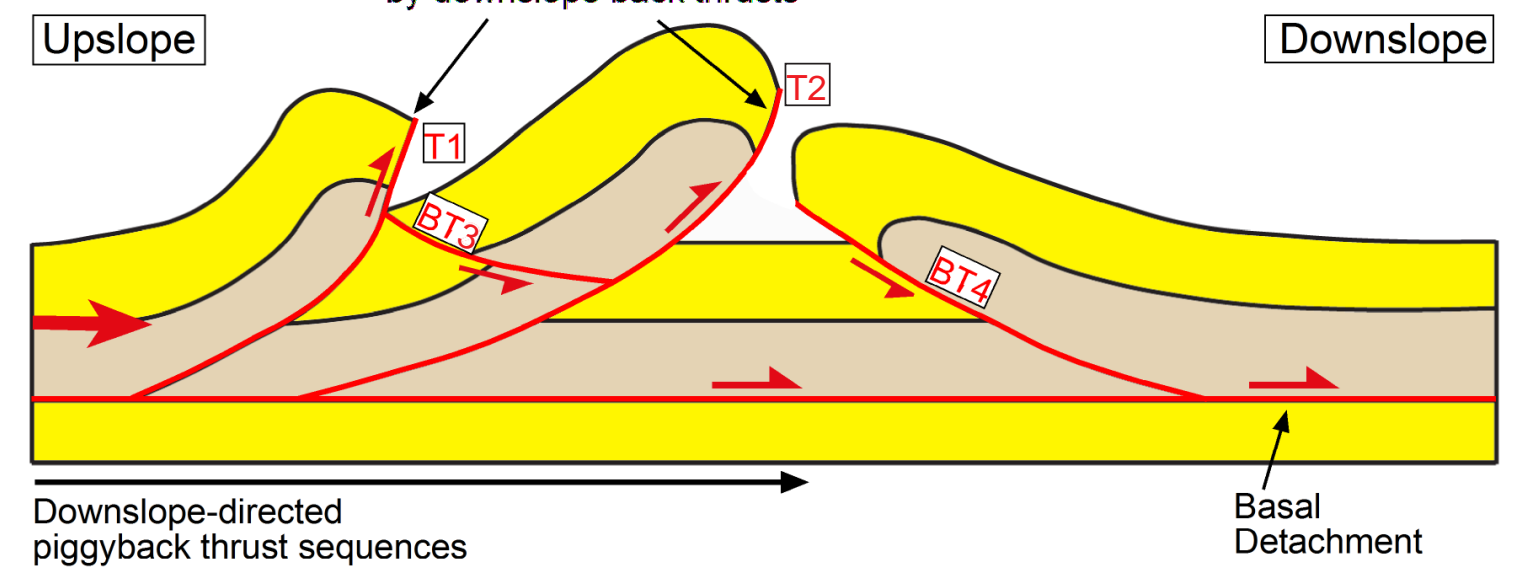

b)

Back thrusts are over steepened by downslope verging fore thrusts

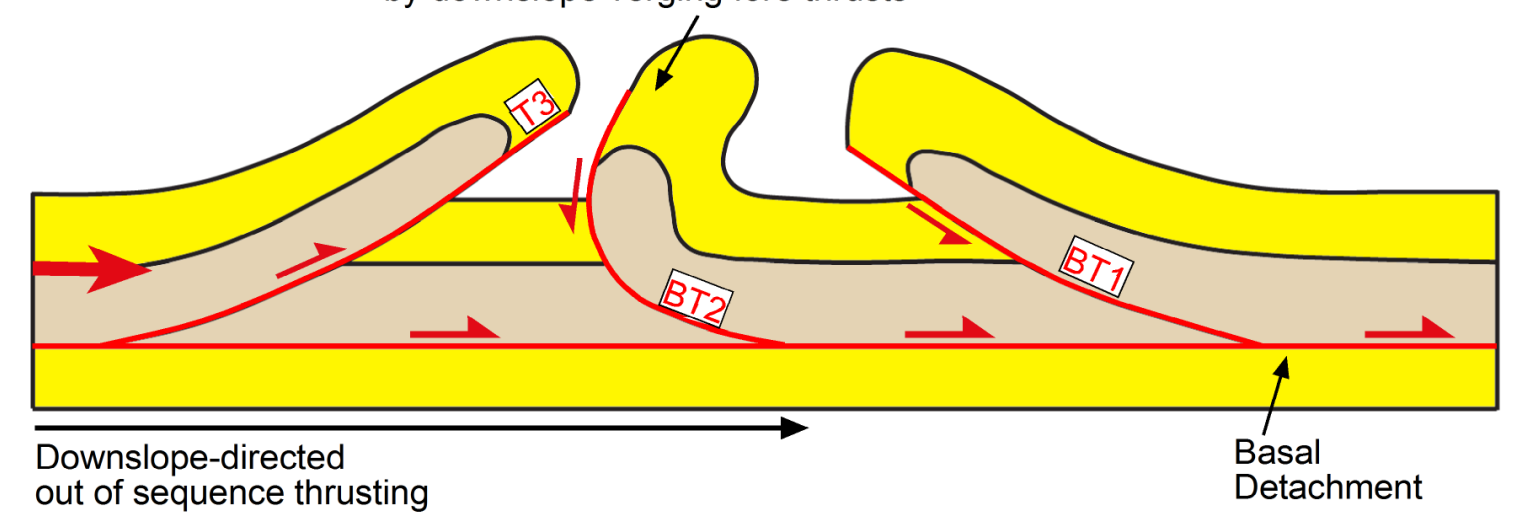

c) Back thrusts are steepened by younger back thrusts in footwall

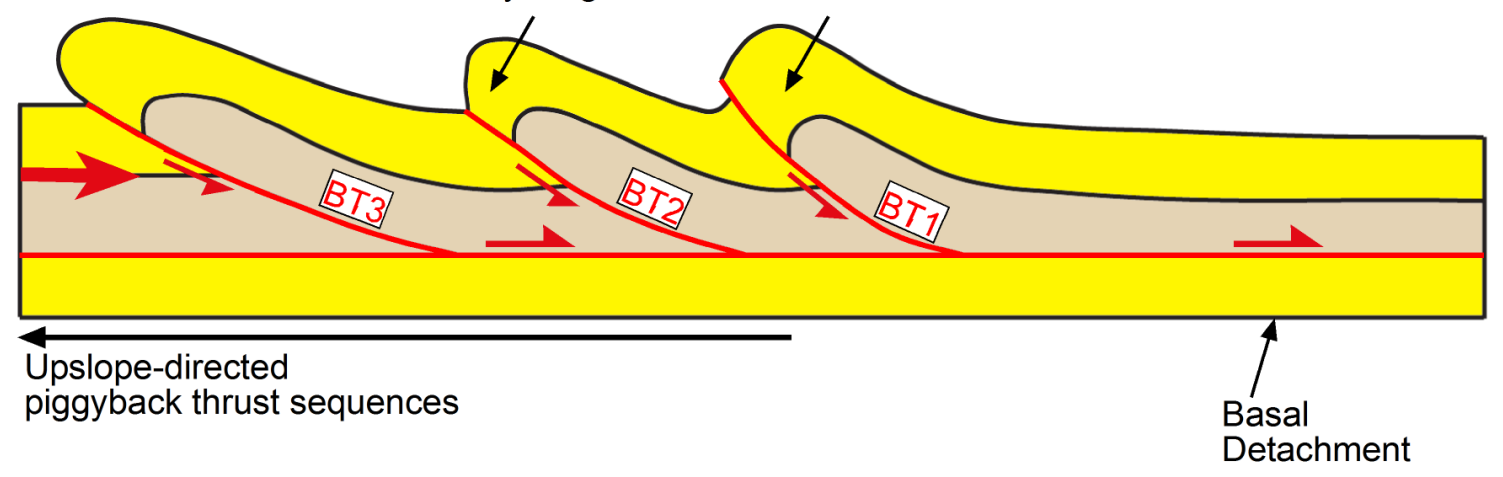

d) $\begin{array}{ll}\text { 'Pinched' } & \text { Back thrust raised } \\ \text { above general leve }\end{array}$ Sedimentary cap thins

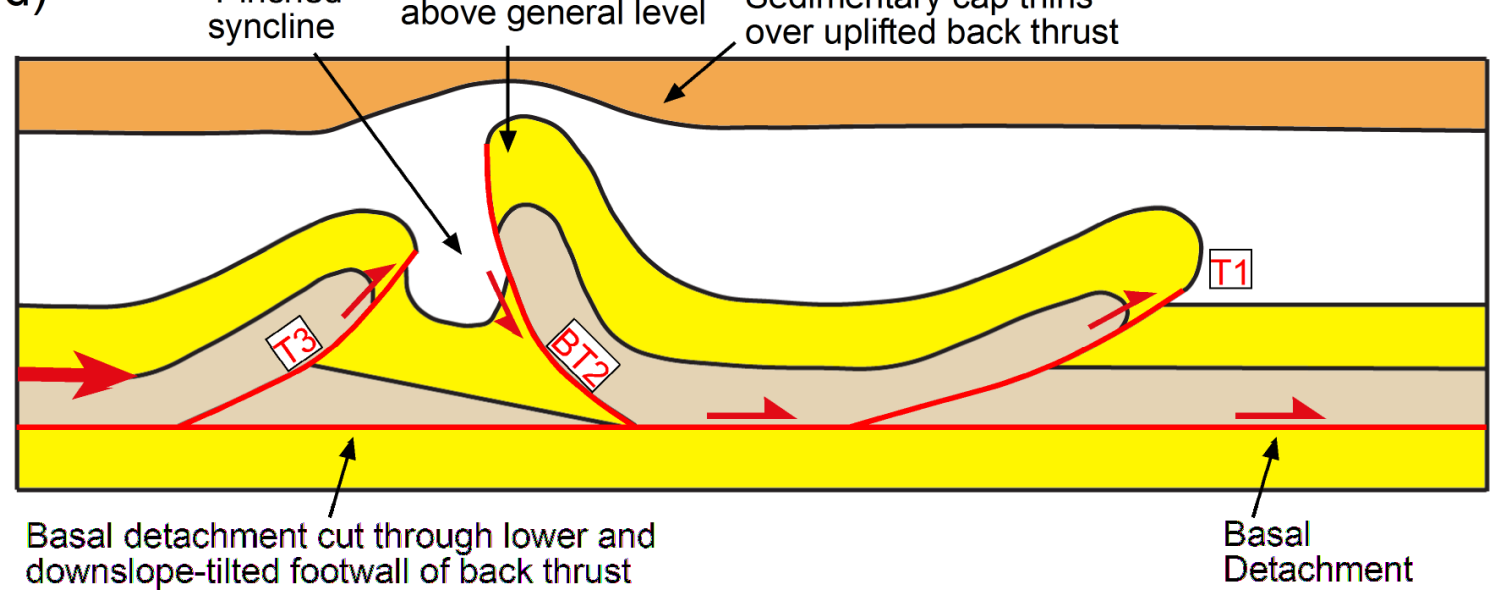


a) Upslope

Back thrusts formed above weak basal detachment

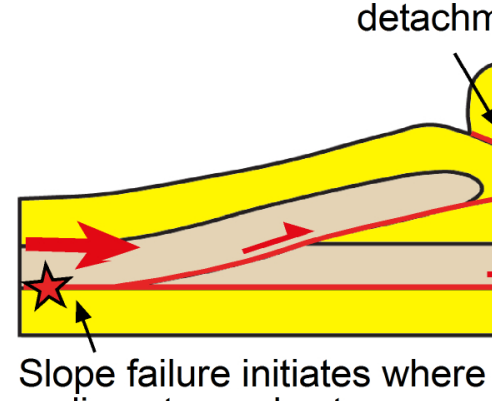
sediments weakest
Fore thrusts mark emergent toe that accelerates during unconfined flow over sediment surface

\section{Velocity of $d$
b) Upslope}

Fore thrusts developed where basal detachment has greater velocity

\section{.}

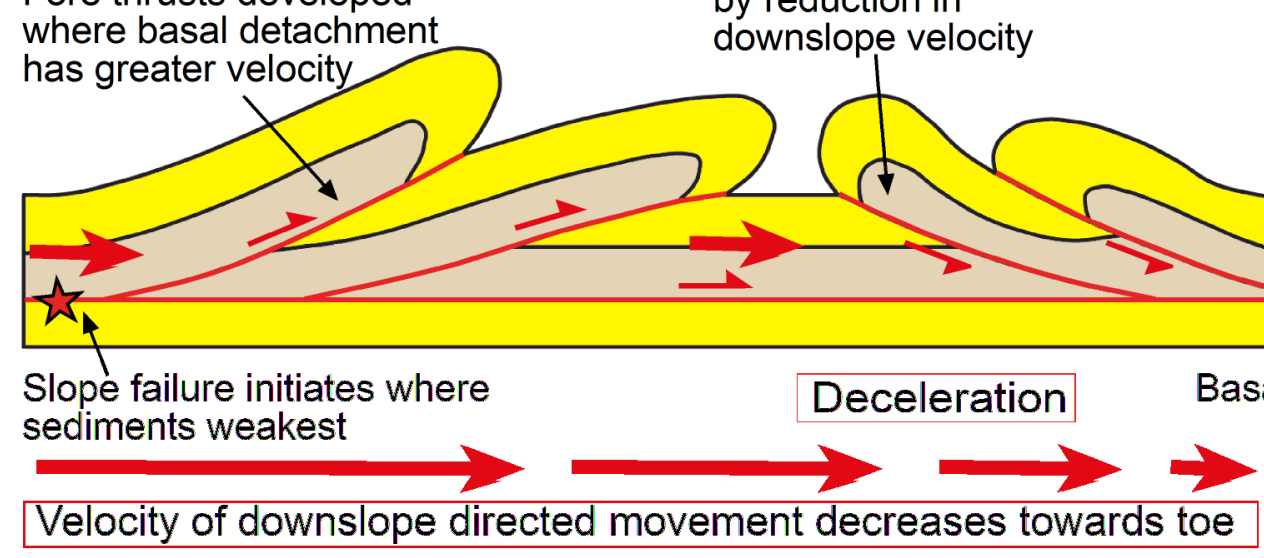

Back thrusts formed by reduction in

Deceleration

Basal detachment

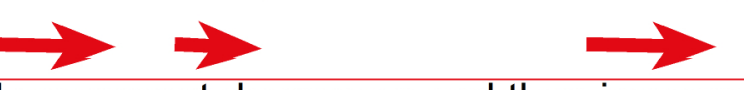

\section{Acceleration}

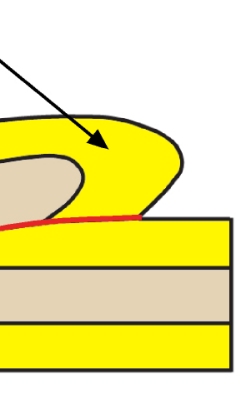

wnslope directed movement decreases and then increases towards toe

Downslope

Non-emergent 'open-ended' toe absorbs deformation by lateral compaction Velocity of downslope directed movement decreases towards toe 

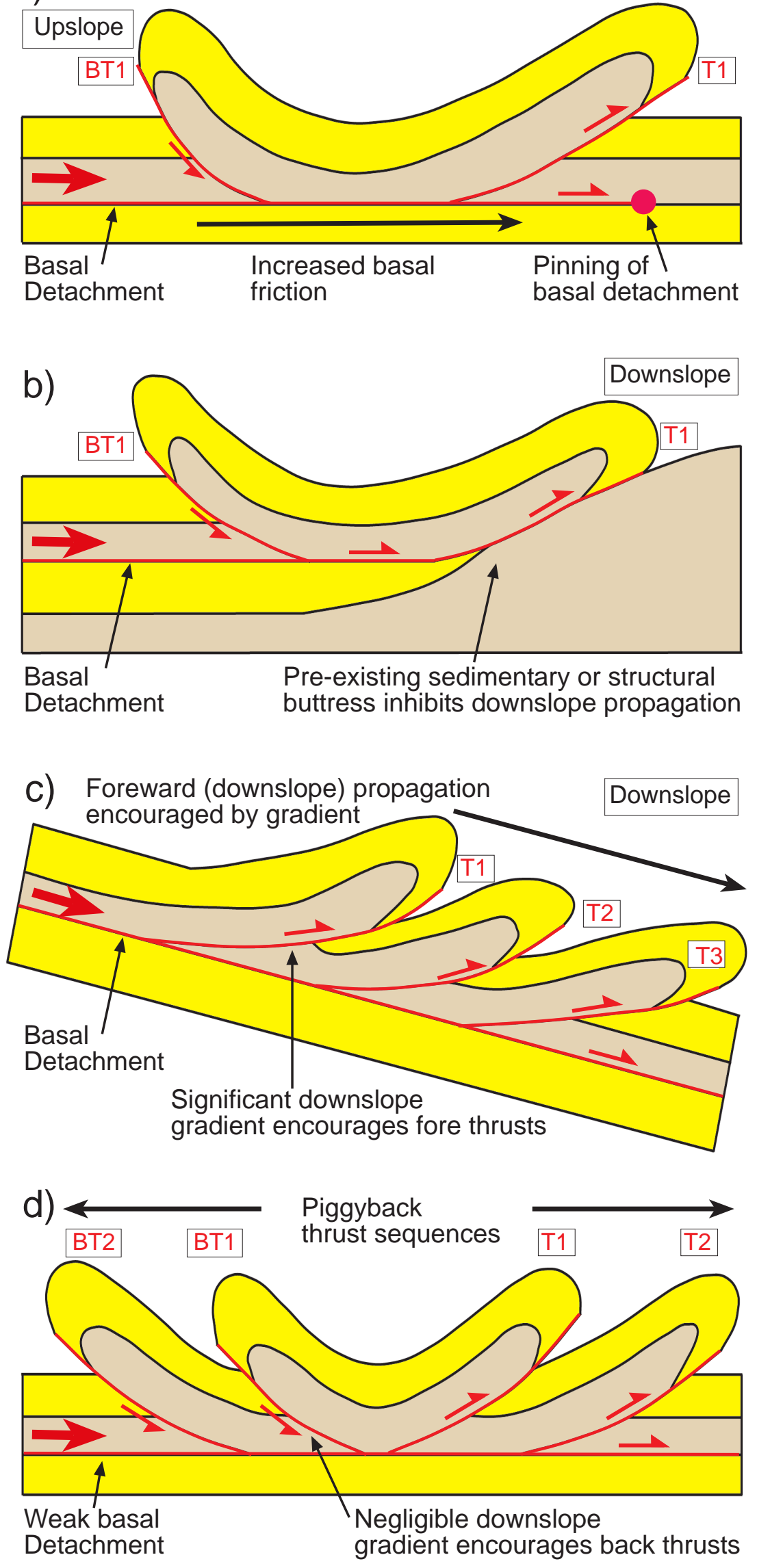
a)

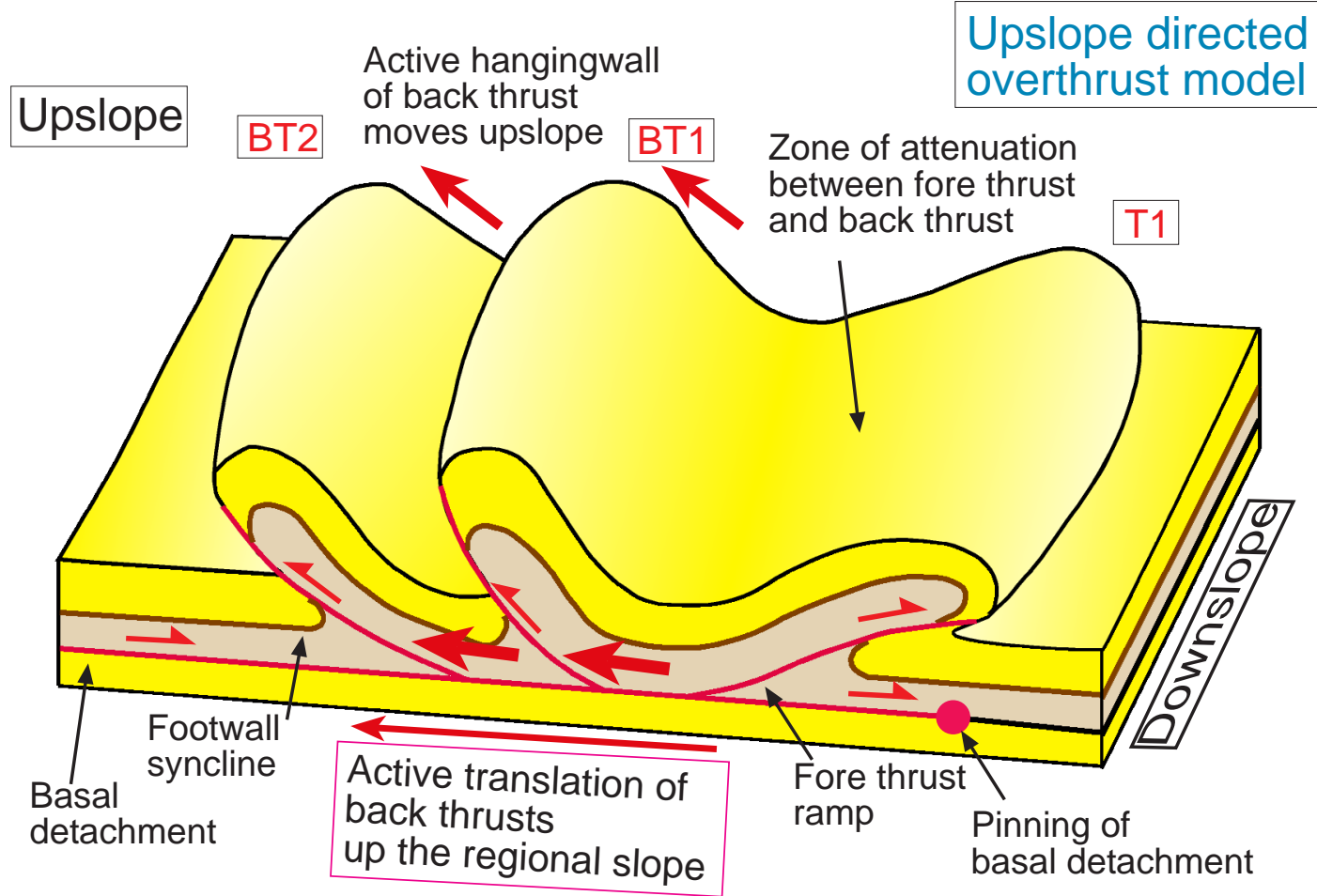

b)
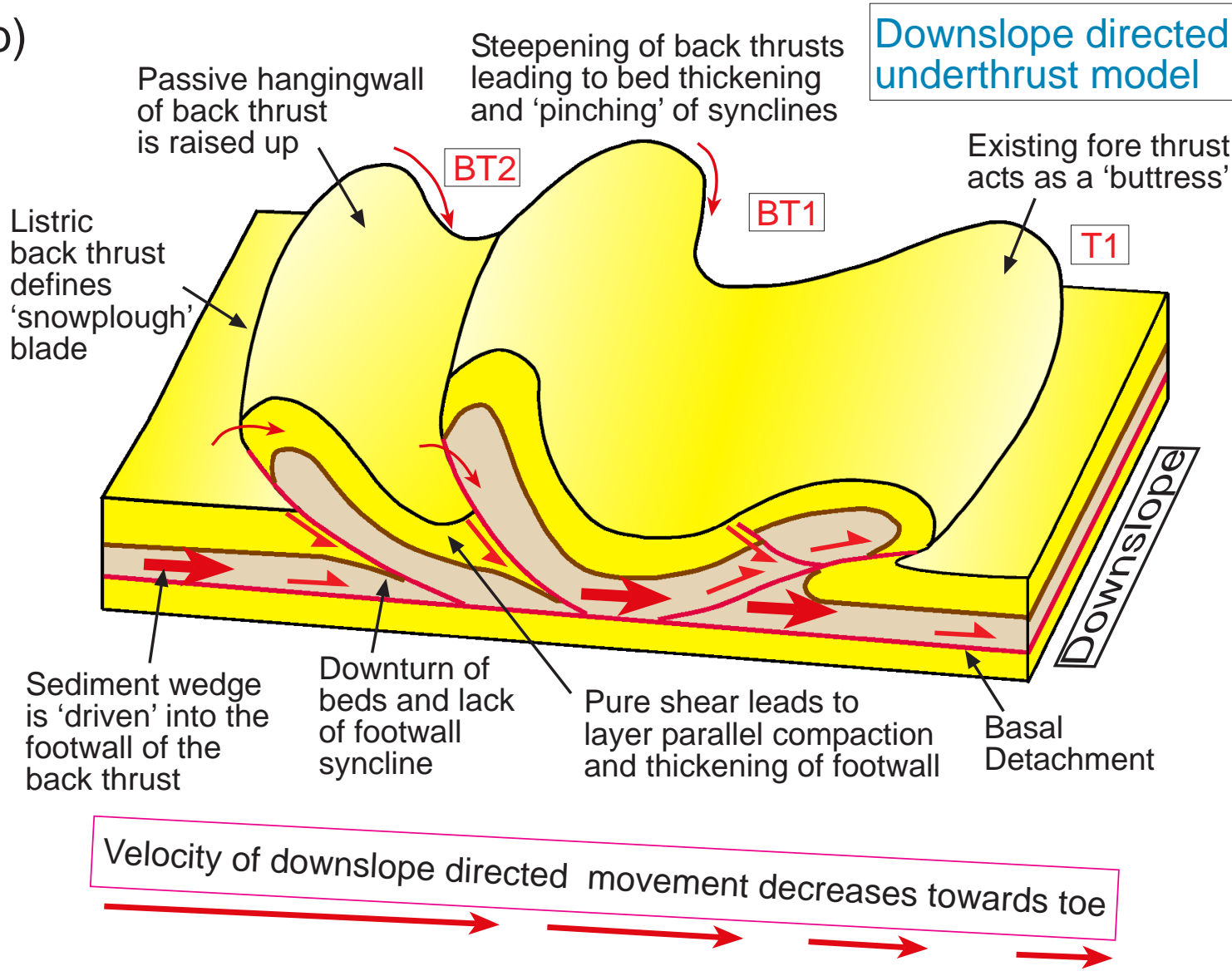